\title{
Site-Response Models for Charleston, South Carolina, and Vicinity Developed from Shallow Geotechnical Investigations
}

\author{
by M. C. Chapman, J. R. Martin, C. G. Olgun, and J. N. Beale
}

\begin{abstract}
The study models the response of near-surface materials in Charleston, South Carolina, and the adjacent area. Geotechnical investigations at 281 locations were made available by local engineering firms. The data used for dynamic siteresponse analysis were derived from shear-wave velocity measurements at 52 locations. Site response was quantified as the ratio of surface motion to hypothetical hard-rock basement outcrop motion. Scenario earthquake motions were developed with the stochastic model. Acceleration response ratios for 5\% critical oscillator damping were computed for 12 frequencies ranging from 0.1 to $30 \mathrm{~Hz}$ and for peak ground acceleration.

Two features determine the general nature of site response in the study area: the impedance contrast between Mesozoic basement and Cretaceous sediments, and the shallow impedance contrast between Quaternary and Tertiary sediments. Average Swave velocities in the Quaternary are relatively uniform and range from 150 to 250 $\mathrm{m} / \mathrm{sec}$. They are not strongly correlated with surface geology. The velocities of the immediately underlying Tertiary sediments range from 300 to $500 \mathrm{~m} / \mathrm{sec}$. Because of the uniformity of velocity in the Quaternary, depth to the Quaternary-Tertiary contact appears to be the most important variable leading to differences in calculated site response. This surface is irregular, and varies in depth from near surface at inland sites to approximately $30 \mathrm{~m}$ at sites near the coast. As a consequence, estimated site response in the frequency band $1-10 \mathrm{~Hz}$ varies by as much as a factor of 3 . Site response at frequencies less than $1 \mathrm{~Hz}$ is dominated by the first few resonant harmonics of the entire sedimentary section, with fundamental frequency near $0.2 \mathrm{~Hz}$.
\end{abstract}

\section{Introduction}

Charleston, South Carolina, experienced a magnitude $7+$ earthquake in 1886 (Dutton, 1889; Bollinger, 1977; Johnston, 1996). Paleoseismic investigations have shown evidence for several prehistoric liquefaction-inducing earthquakes in coastal South Carolina in the past 6000 years (Talwani and Schaeffer, 2001), and the area has the highest estimates of seismic hazard along the eastern coast of the United States (Frankel et al., 1996, 2002).

Charleston is situated on approximately $800-900 \mathrm{~m}$ of Cretaceous and younger sediments of the Atlantic Coastal Plain. These sediments overlie Mesozoic and Paleozoic basement rocks with high shear-wave velocity. The Tertiary and Cretaceous sediments are compacted and weakly lithified, but at most locations in Charleston and in the immediately surrounding area, the near-surface materials are unconsolidated Quaternary marine and estuarine sands and clays. These young, shallow materials were last subjected to strong motion in 1886, resulting in more than $80 \mathrm{~km}$ of railroad track to the north and west of the city being severely damaged by lateral and vertical displacement. Sand expul- sion, ground fissuring, and lateral spreading were observed over an area of $1300 \mathrm{~km}^{2}$. In the city of Charleston, which is approximately $25 \mathrm{~km}$ to the south and east of the area of maximum ground deformation, ground settlement and sand blows were common, most buildings were severely damaged by shaking and ground failure, several were destroyed, and 60 people were killed (Dutton, 1889; Stover and Coffman, 1993). The near-surface geological units in this area have not been subjected to strong motion since 1886 , and there is at present a lack of instrumental data for an empirical assessment of site response.

This study models the response of near-surface geological units in the Charleston area to strong ground motion on the basis of recent geotechnical investigations of the shallow subsurface. A comparison and validation of the modeling results with instrumental measurements is not possible at this time because of the lack of both strong and weak ground motion data in the immediate Charleston area where the investigations were performed. The purpose of this study is to examine the degree to which the shallow materials that have 
been investigated may affect the site response in this area of significant seismic hazard and to identify those geological elements that may influence gross characteristics of ground motion in the area. It is hoped that this investigation will provide some basic information for hazard assessment and insight into the needs for future instrumental ground-motion data acquisition to better quantify site response.

The study area is approximately $1650 \mathrm{~km}^{2}$ in extent and includes portions of Charleston, Dorchester, and Berkeley counties, south of $33.0^{\circ} \mathrm{N}$ latitude and between $80.25^{\circ} \mathrm{W}$ and $79.75^{\circ} \mathrm{W}$ longitude. The main area of interest is within a $20-\mathrm{km}$ radius of the city of Charleston. Some previous siteresponse investigations in the study area have been done on a site-specific basis for major construction projects. A recently published study by Silva et al. (2003) developed scenario ground motions for South Carolina as part of a comprehensive earthquake loss and vulnerability evaluation. In that study, site-response amplification factors were developed for four general site-response categories reflecting geological conditions statewide in South Carolina, including the Charleston area. Here, we model site response in the Charleston area in detail.

Geologic mapping by the U.S. Geological Survey is used to characterize the geological units exposed at the surface. Local engineering firms generously provided geotechnical data consisting of 281 standard penetration tests and cone penetrometer tests. Shallow shear-wave velocity measurements at 52 locations from seismic cone penetrometer tests are included. This article describes the modeling of site response at the 52 sites for which shear-wave velocities at shallow depths have been directly measured by down-hole velocity profiles in the course of routine cone penetrometer testing. Deeper shear-wave velocity measurements from three suspension logs at two bridge sites provide constraint in the important depth range $25-100 \mathrm{~m}$ in the Tertiary units underlying the study area. We also describe preliminary regression models of shear-wave velocity as a function of penetrometer tip resistence, effective overburden pressure, and lithology.

The geotechnical data are used to develop layered soil models. The lithology is taken directly from the standard penetration test (SPT) logs or inferred from the cone penetration test (CPT) results.

We calculated site response at each of the 52 geotechnical exploration sites for which directly measured shearwave velocities were available by using an equivalent linear algorithm implemented by the program SHAKE (Schnabel et al., 1972). The response is quantified in terms of the ratio of soil-surface motion to hypothetical hard-rock (preCretaceous) basement outcrop motion. Absolute acceleration response ratios for $5 \%$ critical oscillator damping are computed for 12 oscillator frequencies ranging from 0.1 to $30 \mathrm{~Hz}$ and for peak ground acceleration. Scenario earthquake motions for the basement input were developed using the stochastic model. For each site, a series of 20 simulations were made for each of five reference basement rock outcrop input motion amplitude levels. The levels are 0.1, 0.2, 0.3, 0.4 , and $0.5 \mathrm{~g}$ peak ground acceleration. The mean site response for a given oscillator frequency is estimated from the mean of the 20 simulations for each input motion level. The results of the dynamic analysis are examined for correlation and dependence on mapped geology and shallow geological structure.

\section{Geology of the Study Area}

The Atlantic Coastal Plain geological province is a seaward thickening wedge of Cretaceous and younger sediments approximately 800-900 m thick in the study area. The section consists of unlithified sediments interbedded with weakly lithified units. Units exposed in the study area include marine, marginal-marine, and fluvial-estuarine sediments, ranging in age from Oligocene to Holocene. Surface exposures over most of the area are Pleistocene to Holocene sands and clays, along with artificial fill and spoil. Tertiary units are exposed in small areas in the north and northwest sections of the study area, primarily along stream banks.

Figure 1 is a geological map of the study area. Table 1 gives a brief description of the units present at the surface and in the shallow subsurface. The following brief discussion is taken from the work of Weems and Lemon (1984, 1988, 1993), McCartan et al. (1984), and Weems et al. (1997). Refer to the extensive work of these authors for detailed descriptions of lithology, geological profiles, and discussion of the geological history of the study area.

\section{Tertiary Units in the Shallow Subsurface}

Tertiary units at shallow depths in the study area are well compacted and in some cases partially lithified. The oldest Tertiary units commonly encountered in geotechnical borings in the shallow subsurface are impermeable limestones of the Cooper Group, which includes the Eocene Parkers Ferry and overlying Oligocene Ashley formations. The Parker's Ferry is not exposed at the surface in the study area, although both it and the Ashley are ubiquitous in the subsurface. It is a dense, sticky lime mudstone. The Ashley formation is a tough phosphatic calcarenite. It is an important unit for foundation embedment of major construction in the study area. It resists erosion and is exposed along stream banks in the northwestern section of the study area. The overlying Oligocene Chandlers' Bridge formation is a phosphatic sand that is easily eroded; exposures are sparse. In general, the Pliocene Goose Creek Limestone is a soft calcarenite that is easily eroded, with only very minor exposure in the study area.

\section{Quaternary Units}

Quaternary deposits are easily eroded unconsolidated sediments deposited in back-barrier lagoon, beach-barrier island, and shallow marine environments during interglacial 


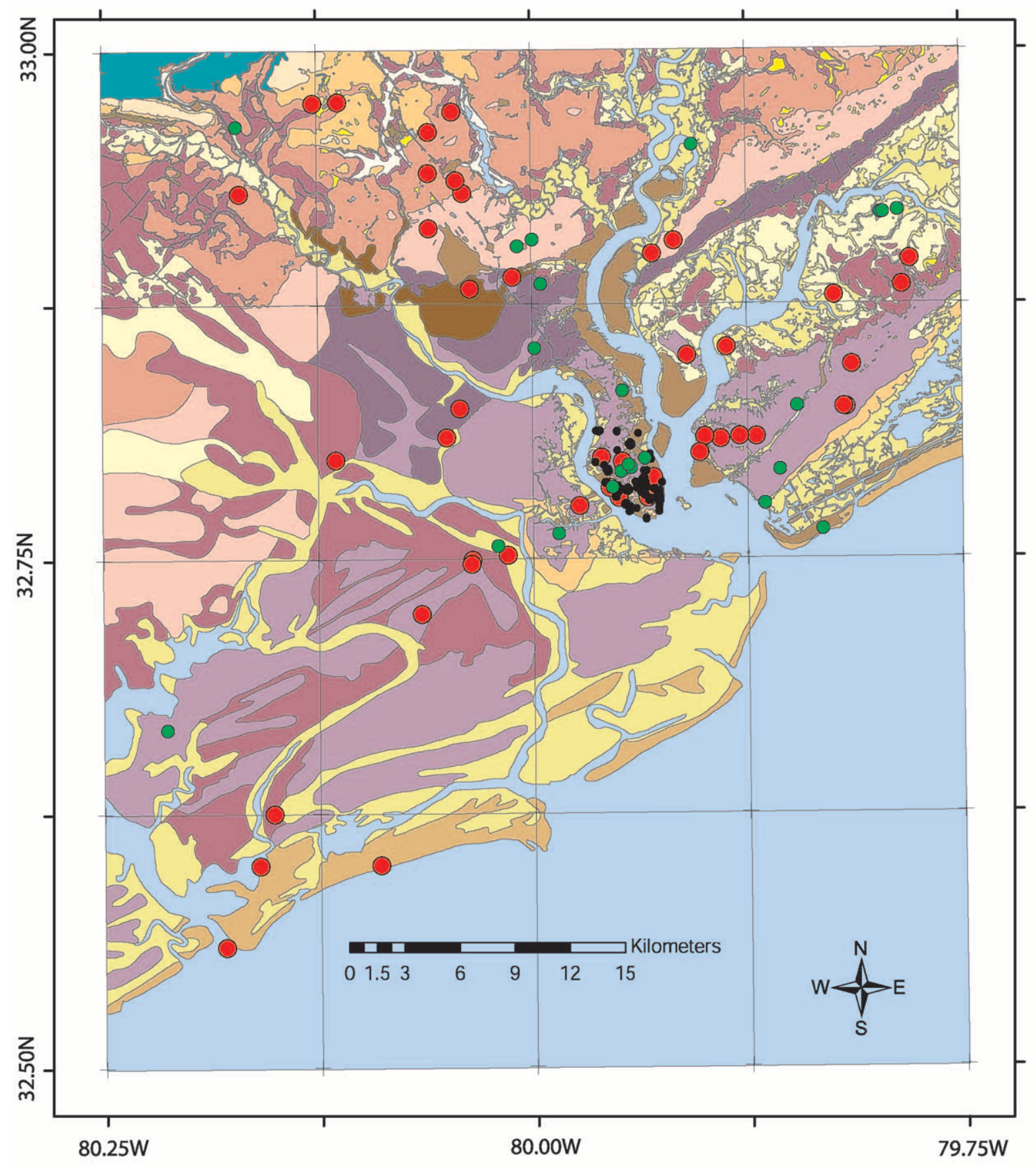

\section{- Cone Penetrometer Test GEOLOGY TYPE

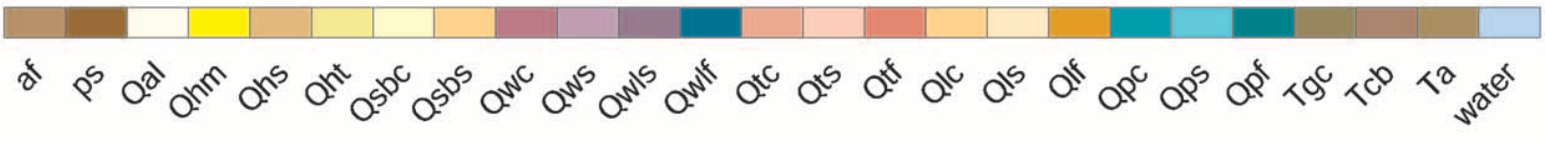

Figure 1. Geological map of the study area with locations of geotechnical tests shown as filled circles. The geotechnical data include cone penetration tests, seismic cone penetration tests, and standard penetration tests. The geological map is derived from Weems and Lemon (1988, 1993, 1994), McCartan et al. (1984), and Weems et al. (1997). Table 1 lists the geological descriptions of the various mapped units. 
Table 1

Description of Shallow Geological Units

\begin{tabular}{|c|c|}
\hline Unit & Description* \\
\hline Qal & Holocene alluvium: sands in drainages. \\
\hline Qhm & Pleistocene to Holocene freshwater stream and swamp deposits. Thin deposits of peat and muck. \\
\hline Qhs & Holocene beach and barrier island deposits. Fine-grained, well-sorted quartz sand. \\
\hline Qht & Holocene tidal marsh deposits. Clayey sand and clay, organic rich. \\
\hline Qsbc & Pleistocene (33-85 ka) Silver Bluff beds. Estuarine deposits, silty to sandy clay and quartz sand. \\
\hline Qsbs & Pleistocene (35-85 ka) beach and barrier island deposits. Fine-grained with minor course-grained fraction. \\
\hline Qwe & Pleistocene Wando formation (70-130 ka). Estuarine facies. Clayey sand and clay. \\
\hline Qws, Qwls & Pleistocene Wando formation (70-130 ka). Beach-barrier island facies. Quartz sand, fine grained. \\
\hline Qwlf & $\begin{array}{l}\text { Pleistocene Wando formation ( } 70-130 \mathrm{ka} \text { ) fossiliferous shelf-sand facies, quartz sand, fine to medium grained, phosphatic, bioturbated. } \\
\text { Up to } 4.5 \mathrm{~m} \text { thick, and present only in the subsurface. }\end{array}$ \\
\hline Qtc & Pleistocene (200-240 ka) Ten Mile Hill beds (informal) clayey sand and clay, fluvial and estuarine deposits. Up to $20 \mathrm{~m}$ thick. \\
\hline Qts & $\begin{array}{l}\text { Pleistocene (200-240 ka) Ten Mile Hill Beds (informal) beach and barrier island deposits, fine- to medium-grained quartz sand. } \\
\text { Up to } 15 \mathrm{~m} \text { thick. }\end{array}$ \\
\hline Qtf & $\begin{array}{l}\text { Pleistocene ( } 200-240 \mathrm{ka} \text { ) Ten Mile Hill beds (informal) fossiliferous sand facies, fine to medium grained, up to } 10 \mathrm{~m} \text { thick. Present in } \\
\text { subsurface: exposure limited to stream banks in North Charleston area. }\end{array}$ \\
\hline Qlc & $\begin{array}{l}\text { Pleistocene }(0.25-0.75 \mathrm{ma}) \text { Ladson formation, fluvial-estuarine facies. Medium-grained, poorly sorted clayey sands, and clays. } \\
\text { Up to } 6 \mathrm{~m} \text { thick. }\end{array}$ \\
\hline Q1s & Pleistocene $(0.25-0.75 \mathrm{ma})$ Ladson formation, barrier sand facies. Quartz sand, course-grained and poorly sorted. Up to $6 \mathrm{~m}$ thick. \\
\hline Qlf & $\begin{array}{l}\text { Pleistocene }(0.25-0.75 \mathrm{ma} \text { ) Ladson formation, fossiliferous shelf-sand facies. Quartz sand, medium to fine grained, well-sorted, } \\
\text { phosphatic, bioturbated. Unit exposed only west of Dorchester Creek and north of Ashley river in northwest section of study area. } \\
\text { Up to } 5 \mathrm{~m} \text { thick. }\end{array}$ \\
\hline Qpc & $\begin{array}{l}\text { Pleistocene ( } 0.75-1.25 \mathrm{ma}) \text { Penholoway formation, fluvial-estuarine clayey sand and clay facies. Exposed in northwest section of study } \\
\text { area. Up to } 4 \mathrm{~m} \text { thick. }\end{array}$ \\
\hline Qps & $\begin{array}{l}\text { Pleistocene }(0.75-1.25 \mathrm{ma}) \text { Penholoway formation, barrier sand facies. Quartz sand, medium to course grained. Present only in a tiny } \\
\text { area in northwest section of study area. }\end{array}$ \\
\hline Qpf & $\begin{array}{l}\text { Pleistocene (0.75-1.25 ma) Penholoway formation, fossiliferous shelf-sand facies. Fine to medium-grained, phosphatic, bioturbated } \\
\text { quartz sand. Exposed in northwest section of study area. Up to } 12 \mathrm{~m} \text { thick. }\end{array}$ \\
\hline $\operatorname{Tgc}$ & $\begin{array}{l}\text { Pliocene ( } 3.5 \mathrm{ma} \text { ) Goose Creek Limestone. Quartzose and phosphatic calcarenite. Exposed along an unnamed creek bank in the northern } \\
\text { section of the study area. Probably less than } 3 \mathrm{~m} \text { thick. }\end{array}$ \\
\hline Tcb & $\begin{array}{l}\text { Oligocene ( } 28 \mathrm{ma} \text { ) Chandler Bridge formation. Quartz phosphate sand, very fine to fine grained. Unconformable contact with underlying } \\
\text { Ashley formation. Up to } 5 \mathrm{~m} \text { thick. Sparse exposures in stream banks in northwest section of study area. }\end{array}$ \\
\hline Ta & $\begin{array}{l}\text { Oligocene ( } 30 \mathrm{ma} \text { ) Ashley formation of Cooper Group. Massive, very fine to fine-grained erosion resistant calcarenite. Exposed in } \\
\text { northwest section of study area. Up to } 30 \mathrm{~m} \text { thick. }\end{array}$ \\
\hline
\end{tabular}

*Adapted from Weems and Lemon (1984, 1988, 1993), McCartan et al. (1984) and Weems et al. (1997).

high sea level stands. Portions of four Pleistocene interglacial beach complexes are preserved in the study area, along with the Holocene beach terrace. Younger beach and lagoon deposits in general lie adjacent to the next older terrace deposits and at lower elevations. Geological map units and formation definition is largely according to individual terrace complex. The formations have been generally divided and mapped according to three facies: fluvial-estuary, beach-barrier island, and marine shelf environments (see, for example, Weems and Lemon, 1988).

The thickness of the Quaternary units in the study area is highly variable, and the units are discontinuous in the subsurface because of very complex spatial variation of depositional environment and postdepositional erosion. Quaternary units exposed at the surface and mapped in the study area include the Penholoway and Ladson formations, the Ten Mile Hill beds, the Wando formation, and the Silver Bluff beds. Clean, well-sorted sands of the beach and barrier island facies of the Ten Mile Hill beds and the Wando formation (units Qtc and Qws, Qwls in Fig. 1) experienced widespread liquefaction in the 1886 earthquake.

\section{Holocene Units}

Freshwater stream and swamp deposits (Qhm) of late Pleistocene to Holocene age consist of peat and muck and are modern to 34,000 years old. These units are exposed at the surface mostly in small rounded depressions on Ten Mile Hill and Wando depositional surfaces. Tidal-marsh deposits (Qht) with ages less than 10,000 years are found in extensive areas adjacent to the Ashley and Cooper rivers, and in other low-lying areas between the younger beach terraces. These deposits are clayey sands and clays. They are soft and organic rich, and they support marsh grass. Holocene alluvium (Qal) consisting mostly of sands is mapped in small areas throughout the study area. Holocene beach and barrier island deposits (Qhs), consisting of well-sorted quartz sand, fine grained, and light grey in color, form the modern coastal beach complex.

Artificial Fill (af) is represented by sands and clays of diverse origin and used for dams, roads, and landfill. It is less than 300 years old. Phosphate-rich spoil from mining operations is indicated by ps in Figure 1. Deposits are lo- 
cated to the northwest of Charleston in the vicinity of the Ashley River.

\section{Velocity Measurements}

Figure 1 shows as red dots the locations of the shallow velocity measurements from the seismic cone penetration tests. Forty-six of the profile locations lie outside the Charleston peninsula in Figure 1. Only six velocity profiles are available for the downtown area. The remaining data points shown in Figure 1 for the downtown Charleston area represent 204 SPTs and six CPTs without shear-wave measurements.

Most of the shallow velocity measurements were made to the depth at which the cone encountered the stiff calcarenite unit of the Tertiary (late Oligocene) Ashley formation, locally referred to as the "Cooper marl." The median maximum depth of the 52 shear-wave velocity profiles is $16 \mathrm{~m}$. Twenty-five percent of the profiles terminated at depths less than $10 \mathrm{~m}$, whereas $25 \%$ terminated at depths greater than $19 \mathrm{~m}$.

Figure 2 shows the minimum, median, and maximum interpreted layer shear-wave velocities as a function of depth derived from the 52 shallow velocity investigations. The increase in median velocity beginning at a depth of approximately $10 \mathrm{~m}$ in Figure 2 is due to the velocity increase associated with the transition from soft Quaternary deposits to stiffer deposits of Tertiary age, in particular, the Ashley formation. The depth to this calcarenite varies across the study area. Individual interval velocity profiles typically exhibit a marked velocity increase upon encountering this unit. The apparent smooth increase in the median velocity versus depth profile shown in Figure 2 largely reflects the variable depth to the Ashley at the different test sites.

Nonlinear dynamic analysis requires the specification of lithology, principally a distinction between clay and sand in the subsurface. We interpreted the shear-wave velocity and CPT data provided by the engineering firms in terms of a layered structure by using standard geotechnical procedures (e.g., Campanella et al., 1995; Lunne et al., 1997). For example, Figure 3 shows CPT logs and velocities derived for a site in Mt. Pleasant, South Carolina, across the Cooper River to the east of the Charleston peninsula. The cone tip resistance tends to be high for sands and low for clays. Conversely, the friction ratio (FR) (sleeve friction divided by tip resistance) typically exhibits low values for sands and high values for clays. The pore water pressure and pore pressure ratio are important diagnostics in the study area. In general, the pore pressures are higher for clays than sands. The calcarenites of the Cooper Group, in particular, the Ashley formation, usually exhibit higher pressures and pressure ratios than typical clays. This behavior, along with an increase in shear-wave velocity, characterizes that unit. In Figure 3, we distinguish the sands from clays at shallow depths on the basis of opposing values of tip resistance and friction ratio. Below the water table, at about $3 \mathrm{~m}$ in Figure 3, the pore

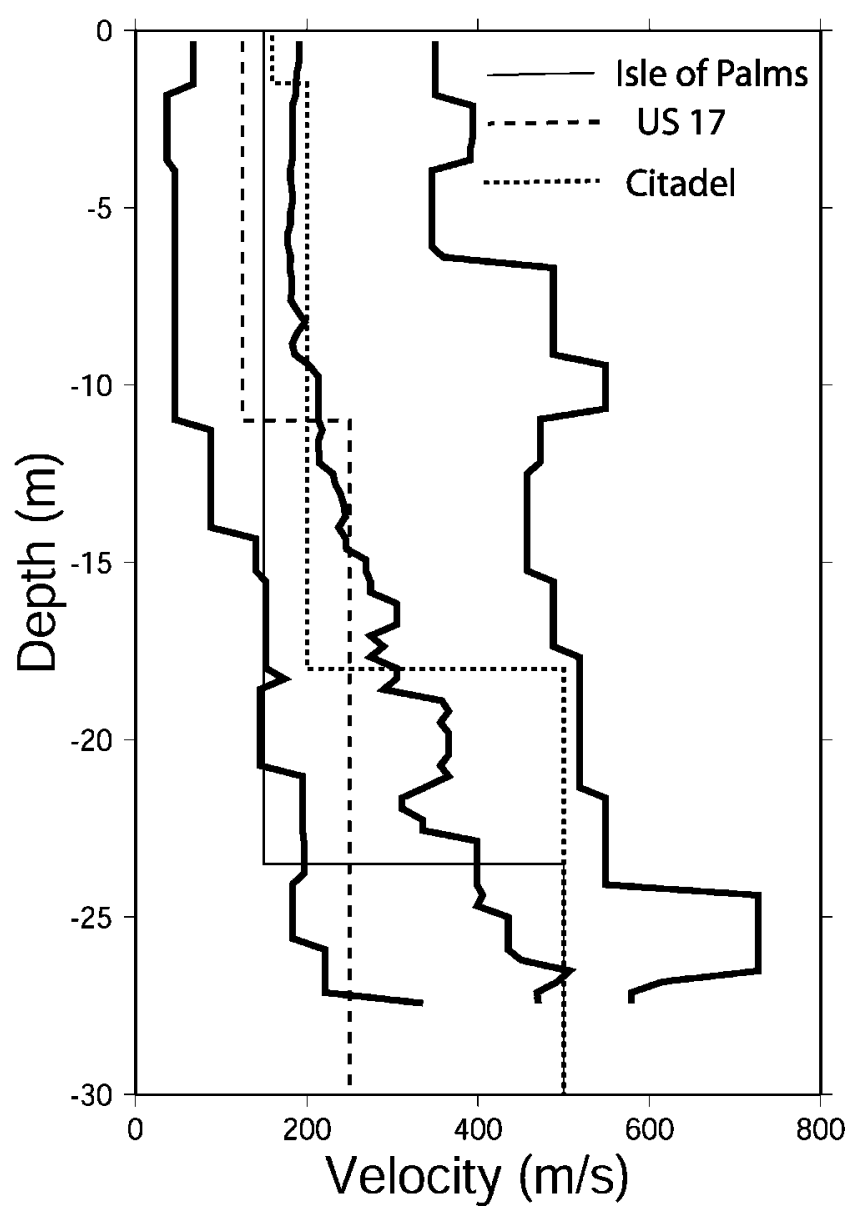

Figure 2. Thick lines show the minimum, median, and maximum shear-wave velocities obtained from 52 shallow shear-wave velocity profiles in the study area. Velocity profiles from refraction experiments by Williams et al. (2000) are indicated by the thin lines.

pressure is an additional diagnostic with high values indicating clays. The jump in pore pressure and shear-wave velocity at approximately $12 \mathrm{~m}$ is interpreted as the top of the Ashley formation, or "Cooper marl."

\section{Shear-Wave Velocities in Tertiary} and Older Sediments

Shear-wave velocity measurements in the depth range from 17 to $105 \mathrm{~m}$ were made by using the suspensionlogging technique. These investigations were made for the new Cooper River Bridge that will connect the cities of Charleston and Mt. Pleasant along U.S. Highway 17 and for the Maybank Highway Bridge replacement project, on South Carolina Route 700, connecting Johns Island to James Island across the Stono River.

Figure 4 shows the velocity profiles obtained at the Cooper River Bridge site. One profile was obtained at the location of the main pier in the Cooper River. Another profile was made at the eastern approach to the bridge, near the bank of the Cooper River in Mt. Pleasant. The profiles at the 

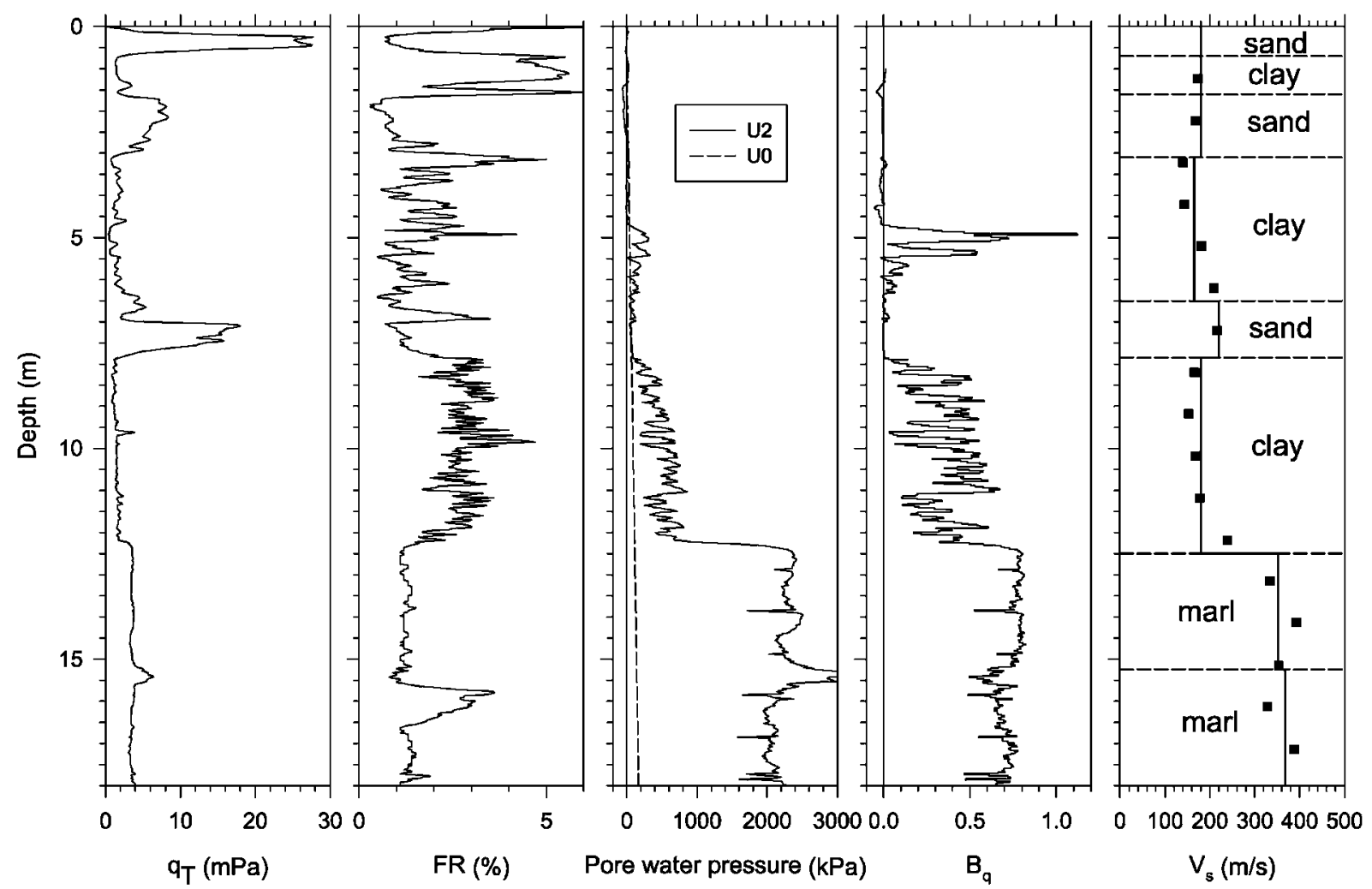

Figure 3. Left to right: $q_{T}$ is corrected cone tip resistance, FR is the ratio of sleeve friction to tip resistance, $\mathrm{U} 0$ is hydrostatic pressure, U2 is measured pore pressure during penetration, $B_{q}$ is the pore pressure ratio, $(\mathrm{U} 2-\mathrm{U} 0) /\left(q_{\mathrm{T}}-\sigma_{v \mathrm{o}}\right)$, where $\sigma_{v \mathrm{o}}$ is the total vertical confining pressure. The square symbols at right indicate measured shearwave velocities, and the dashed and solid lines distinguish interpreted soil types and layer velocities.

Cooper River Bridge are approximately $0.5 \mathrm{~km}$ apart and show gross similarities, but the velocities differ substantially in detail.

The Maybank Highway Bridge profile was located approximately $7 \mathrm{~km}$ to the west of the Charleston Peninsula. It shows lower velocities in the depth range from 20 to $60 \mathrm{~m}$, in comparison with the Cooper River site. The velocity logs at the bridge sites differ in detail, but all exhibit a substantial, systematic increase in velocity from approximately $350 \mathrm{~m} /$ $\mathrm{sec}$ at $50 \mathrm{~m}$ to approximately $700 \mathrm{~m} / \mathrm{sec}$ at $100 \mathrm{~m}$.

It was necessary to develop a scheme to systematically estimate continuous layered velocity versus depth profiles for each of the 281 sites considered in this study. Only two profiles in the entire data set have continuous $S$-wave velocity logs from the surface to $100 \mathrm{~m}$ (Fig. 4). Interpolation for the remaining data presents a difficulty and is uncertain because the three deep profiles at the bridge sites demonstrate substantial lateral variability in the velocity profiles at depths between 20 and $100 \mathrm{~m}$. Also, the shear-wave velocities from $100 \mathrm{~m}$ to the top of the Mesozoic basement at approximately 800-900 m are not measured from down-hole methods.

We have arbitrarily chosen to use the velocity log from the main pier of the Cooper River Bridge as the "standard" for the study area for the depth range $20-100 \mathrm{~m}$. In cases where the site-specific shallow velocity measurements (or other geotechnical data used to indirectly infer velocity) terminated at a depth of less than $20 \mathrm{~m}$, the intervening data gap was spanned by introducing five additional model layers. The velocities of these intervening layers were assigned by linear interpolation between the deepest site-specific velocity determination and that corresponding to the top of the bridge site suspension log profile $(424 \mathrm{~m} / \mathrm{sec}$ at $20 \mathrm{~m})$. In the remaining cases where site-specific velocity information was available to depths exceeding $20 \mathrm{~m}$, we simply introduced an abrupt transition between the deepest site-specific measurement and the velocity at the same depth from the suspension logs. Examples of both situations are illustrated in Figure 5.

The shear-wave velocity profile in the study area for depths greater than $100 \mathrm{~m}$ was inferred from the $P$-wave velocity log determined in the Clubhouse Crossroads no. 1 core hole, located approximately $40 \mathrm{~km}$ to the west of Charleston (Gohn, 1983). Average $P$-wave velocities in the Coastal Plain sedimentary section are also constrained by vertical seismic reflection profiling and refraction studies near Charleston (Ackerman, 1983; Yantis et al., 1983). The 


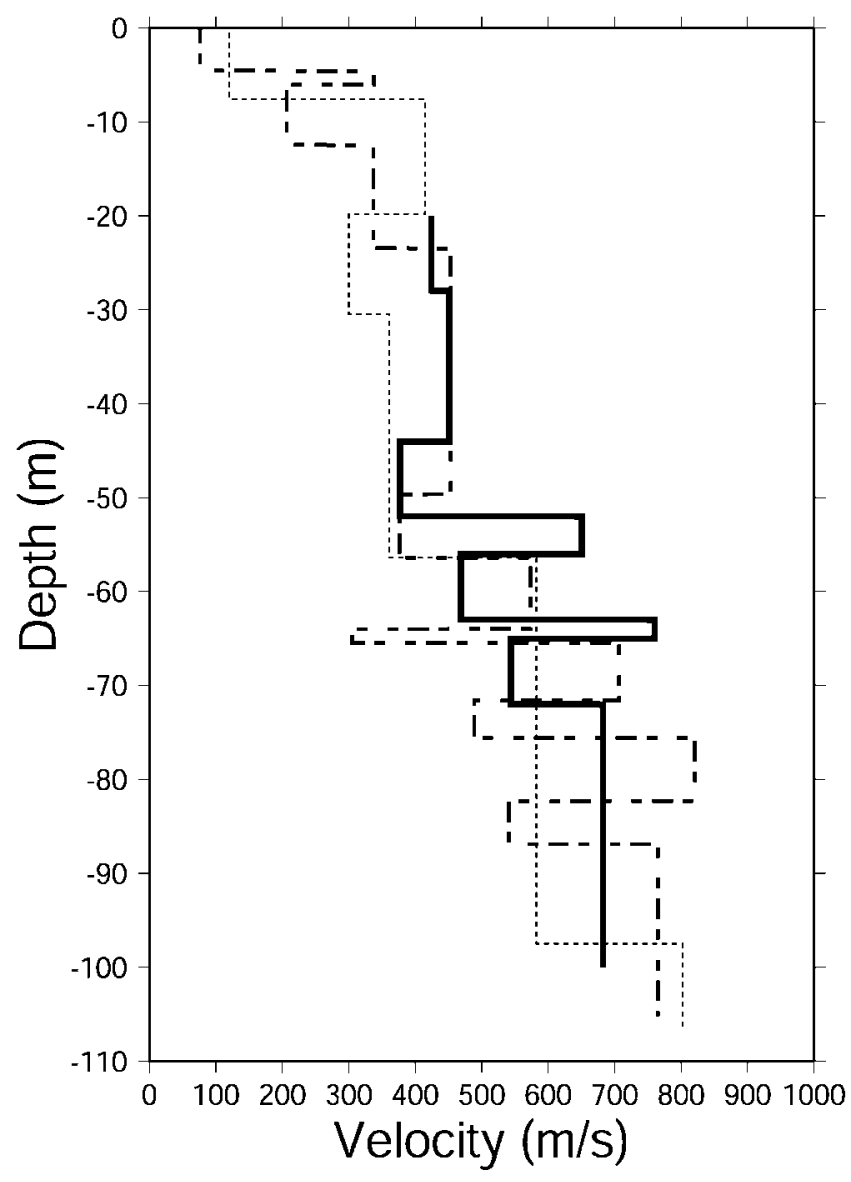

Figure 4. Shear-wave velocity profiles penetrating the Cooper Group at three locations, derived from suspension logs. Thin dashed line, Maybank highway bridge site, Johns Island, South Carolina; heavy dashed line, Cooper River bridge site, eastern approach, Mt. Pleasant, South Carolina; heavy solid line, Cooper River bridge, main pier, Cooper River.

average $P / S$ velocity ratio of 3.06 was determined by an analysis of earthquake data recorded in the area near Summerville-Middleton Place, approximately 30-45 km to the northwest of Charleston (Chapman et al., 2003). The $P$ wave velocity profile from the Clubhouse Crossroads well was interpreted here in terms of a seven-layer model. This model defines the velocity structure used at all sites for the depth range $100-830 \mathrm{~m}$. The shear-wave velocity assumed for the underlying basement half-space is $3.45 \mathrm{~km} / \mathrm{sec}$. This velocity profile is shown in Figure 6.

\section{Prediction of Shear-Wave Velocity from CPT Data}

Twenty-five of the 281 sites examined in this study have CPT data but lack velocity measurements. The 52 seismic CPT (SCPT) investigations were used to develop prediction models for shear-wave velocity in terms of CPT tip resistance, confining pressure and lithology.

Previous estimates of shear-wave velocity $V_{S}$ in terms of CPT tip resistance $q_{c}$ include Rix and Stokoe (1991) for sands using field data collected in Italy, and Mayne and Rix (1993) for clays, derived from a worldwide data set. The data set collected for the Charleston area is large enough to provide a statistically robust estimate of $V_{S}$ in terms of $q_{c}$ and confining pressure for Quaternary sands and clays, as well as for the upper part of the Tertiary Cooper Group.

The 52 seismic CPT test sites provide $223 V_{S^{-}} q_{c}$ pairs for sands with effective overburden pressure $\sigma_{v}^{\prime}$ in the range $8-205 \mathrm{kPa}$. For clay, the data set involves $154 V_{S^{-}} q_{c}$ pairs with $\sigma_{v}^{\prime}$ in the range $12-171 \mathrm{kPa}$. For the Cooper Group ("marl"), the data set consists of $93 V_{S^{-}} q_{c}$ pairs with effective confining pressure $\sigma_{v}^{\prime}$ in the range 59-239 $\mathrm{kPa}$. Figure 7 shows the distributions of measured $V_{S}$ for the sand, clays, and marl, respectively, along with estimates for mean $\log V_{S}$ and standard deviation.

The base 10 logarithms of SCPT shear-wave velocities in meters per second were fit with the following regression models, for sand, clay, and Cooper marl.

$$
\begin{aligned}
& \text { Sand } \\
& \begin{array}{r}
\log V_{S}=(1.476 \pm 0.099)+(0.153+0.026) \\
\log q_{\mathrm{c}}+(0.147 \pm 0.027) \log \sigma_{v}^{\prime}
\end{array} \\
& \mathrm{SEE}=0.110, R^{2}=0.293 \\
& \text { Clay } \\
& \log V_{S}=(1.236 \pm 0.117)+(0.266 \pm 0.033) \\
& \log q_{\mathrm{c}}+(0.072 \pm 0.043) \log \sigma_{v}^{\prime} .
\end{aligned}
$$

\section{Cooper Marl}

$$
\begin{gathered}
\log V_{S}=(1.774 \pm 0.227)+(0.101 \pm 0.058) \\
\log q_{\mathrm{c}}+(0.210 \pm 0.064) \log \sigma_{v}^{\prime} . \\
\mathrm{SEE}=0.093, R^{2}=0.155
\end{gathered}
$$

where

$$
\sigma_{v}^{\prime}=g\left[\rho_{s} h-\rho_{w}\left(h-h_{w t}\right)\right] / 1000 .
$$

In equations (1) (2), (3), $q_{c}$ is measured cone tip resistance $(\mathrm{kPa})$, and $\sigma_{v}^{\prime}$ is the effective overburden pressure $(\mathrm{kPa})$. In equation (4), $g$ is acceleration of gravity $\left(\mathrm{m} / \mathrm{sec}^{2}\right)$, $\rho_{s}$ is material bulk density (assumed to be $2000 \mathrm{~kg} / \mathrm{m}^{3}$ ), $\rho_{w}$ is the density of water $\left(1000 \mathrm{~kg} / \mathrm{m}^{3}\right), h$ is depth of measurement (m), and $h_{\mathrm{wt}}$ is depth of water table. The standard errors of the parameter estimates are given in parentheses; SEE is the regression standard error of estimate.

Figures 8910 show the data and model fits for equations (1) (2), (3). The shear-wave velocity in the sands depends about equally on $q_{c}$ and $\sigma_{v}^{\prime}$, whereas the velocity for the clays depends highly on $q_{c}$, but depends only weakly on 

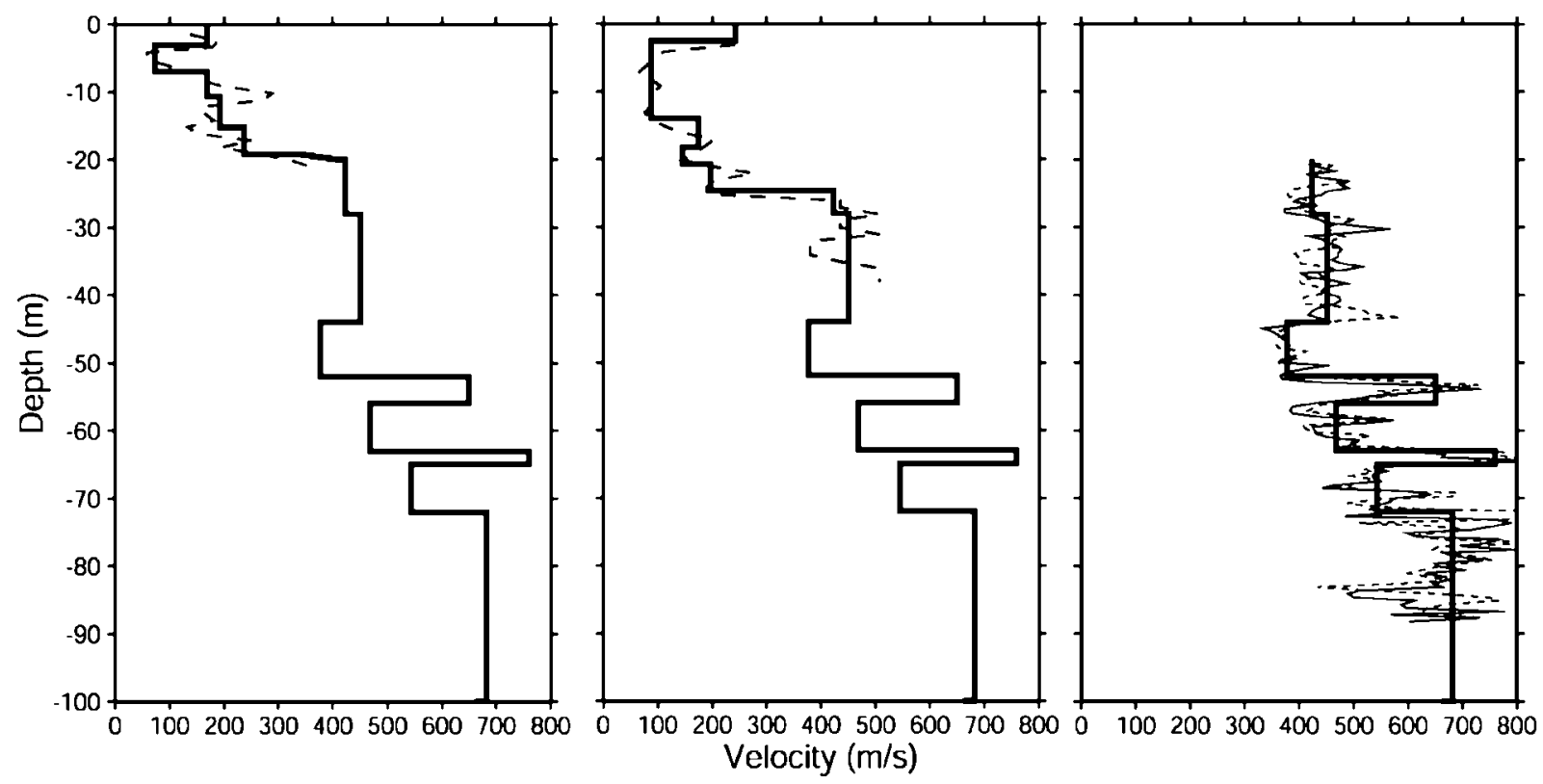

Figure 5. (Left) Shear-wave velocity profile developed for a site where the maximum depth of geotechnical investigation was less than $20 \mathrm{~m}$. (Center) Profile corresponding to the situation where the depth of geotechnical investigation exceeded $20 \mathrm{~m}$. In both cases, the dashed lines indicate measured shear-wave velocity at shallow depth. (Right) Thin dashed and thin solid lines show shear-wave velocity profiles obtained by suspension logging at the main pier of the Cooper River bridge. The thick solid lines show the corresponding interpreted layered velocity structure used for dynamic analysis.

$\sigma_{v}^{\prime}$. In contrast to both sands and clays, the measured velocities for the marl show a stronger dependence on $\sigma_{v}^{\prime}$ than on $q_{c}$.

\section{Prediction of Shear-Wave Velocity from SPT Data}

Most the geotechnical investigations made available for this study are located on the Charleston peninsula. Unfortunately, at 204 of those sites, the data consist only of geotechnical boring logs, with interpreted lithologic layering and SPT blowcounts for each layer. Before 1995, the SPT was used almost exclusively for routine geotechnical investigation, and shear-wave velocity data were not usually collected. Only a few sites have both CPT and SPT measurements.

To potentially make these data useful for dynamic siteresponse analysis, some means of estimating $V_{s}$ as a function of depth by using SPT blowcounts ( $N$ values) is necessary. The approach we follow involves determining the ratios of median $q_{c}$ to median $N$ for sand, clay, and marl lithology in the study area. A rough estimate of $V_{s}$ can be made using equations (1) (2) (3) by converting the measured values of $N$ to estimates of $q_{c}$ using the ratios of median values.

Figure 11 shows the distributions of $\mathrm{q}_{\mathrm{c}}$ and $\mathrm{N}$ for the sand, clay and Cooper marl. Note that the CPT and SPT data are from different sites. For $q_{c}$ in $\mathrm{kPa}$, and $N$ in blows/ft, the data shown in Figure 11 lead to the following estimates: $q_{c}$ l $N=929$ for sands, $q_{c} / N=550$ for clay, and $q_{c} / N=228$ for the Cooper marl. These estimates are based on $1737 \mathrm{~N}$ values for sand, $1426 \mathrm{~N}$ values for clay, and 785 values for marl. Converting $N$ value to $q_{c}$ and estimating $V_{S}$ using equations (1) (2), (3) leads to the distributions shown in Figure 12. A comparison of the results shown in Figure 12 with those shown in Figure 7 for direct measurement of $V_{s}$ indicates good agreement in terms of mean values for sand and clay. The mean value of the SPT-inferred $V_{s}$ for the marl is slightly greater than the mean value in the directly measured data set. This is because the depth to the Cooper marl on the Charleston peninsula is somewhat greater, on average, than at the test sites were the direct velocity measurements were made. This difference in depth, combined with the strong dependence of $V_{s}$ on $\sigma_{v}^{\prime}$ in equation (3), leads to slightly higher mean estimates for the marl velocity using the $\mathrm{N}$-to$q_{c}$ conversion for those sites.

\section{Shear Modulus and Damping Behavior as a Function of Shear Strain}

The response of thick sedimentary deposits to strong motion is a subject of much recent interest, but observational and experimental data are limited. Uncertainty remains for geological conditions similar to the study area where a thick sedimentary sequence overlies an extremely high-velocity basement.

Recent laboratory experiments and modeling results indicate that confining pressures at depth in thick deposits mitigate the reduction of shear modulus and increase in damp- 


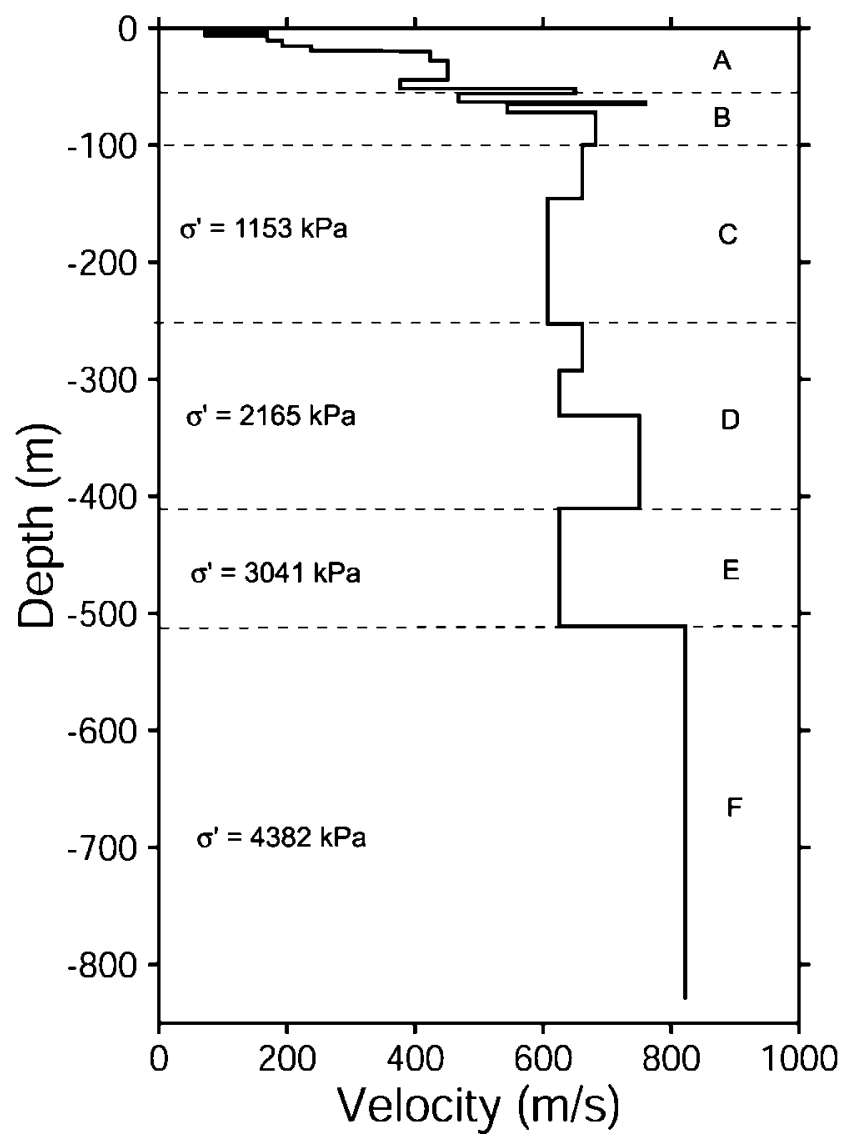

Figure 6. Typical shear-wave velocity profile for the study area. Velocities in the upper part of region A $(0-56 \mathrm{~m})$ are defined on the basis of site-specific geotechnical investigation. Strain-dependent modulus and damping degradation is defined on the basis of site-specific lithology and confining pressure. Velocity in region B $(56-100 \mathrm{~m})$ is inferred from velocity logs at the Cooper River Bridge site. The modulus and damping degradation is that derived from experimental data for the Ashley formation (W. Camp, personal comm., 2002). Velocity in regions C, D, E, and $\mathrm{F}$ is inferred from the $P$-velocity $\log$ at the Clubhouse Crossroads no. 1 corehole site. The modulus and damping degradation models for regions $\mathrm{C}, \mathrm{D}, \mathrm{E}$, and $\mathrm{F}$ are taken from Assimaki et al. $(2000,2001)$ and are functions of mean effective stress $\sigma^{\prime}$, assuming a compaction ratio of 0.3 .

ing observed in laboratory tests at confining pressures appropriate for sediment thicknesses on the order of a few tens of meters (Laird and Stokoe, 1993; Assimaki et al., 2000, 2001; Hashash and Park, 2001). Until recently, predictive shear modulus reduction and damping models for nonlinear dynamic analysis were based on low confining pressure experiments. Such models underpredict surface ground motions in thick deposits.

Confining pressures are particularly important for the dynamic behavior of sands. Ishibashi and Zhang (1993) developed formulas expressing dynamic shear moduli and damping ratios in terms of cyclic shear strain, mean effective

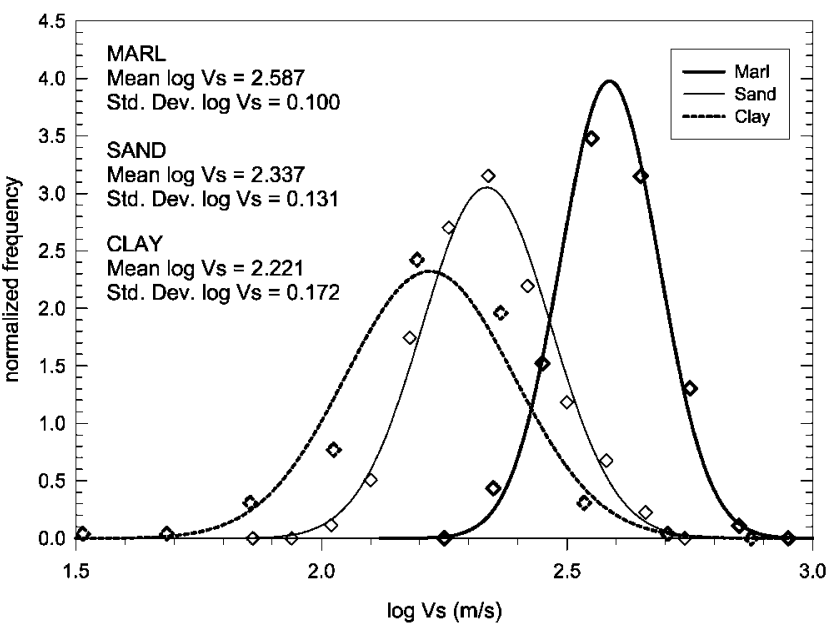

Figure 7. Distribution of measured shear-wave velocity.

confining pressure, and soil plasticity index. Most of their data were obtained at mean effective confining pressures less than $400 \mathrm{kPa}$, representative of depths approximately $60 \mathrm{~m}$ or less.

We use the Ishibashi and Zhang (1993) model for shallow sands in the study area. The effect of confining pressure at shallow depths is modeled using six different relations, for midlayer depths of $1.5,4.5,7.5,10.5,13.5$, and $18.3 \mathrm{~m}$. We have adopted the Ishibashi and Zhang model for $10 \mathrm{~m}$ depth and plasticity index 15 , for all shallow clays.

The Ashley formation, uppermost unit of the Cooper Group, is encountered at depths shallower than $24 \mathrm{~m}$ at almost all the sites we studied. The thickness of the Ashley is variable, but averages approximately $35 \mathrm{~m}$ in the study area. The remaining formations comprising the Cooper Group are the Parker's Ferry and the Harleyville. They are geologically similar to the Ashley, and together, the combined thickness of the Cooper Group is in excess of $75 \mathrm{~m}$ at most locations. The suspension logs at the Cooper River Bridge are entirely within the Cooper Group. We assume that the base of the Cooper Group is at $100 \mathrm{~m}$ in the study area and use experimentally determined shear-modulus reduction and damping values to model the dynamic behavior. These results are based on laboratory tests with samples of material from the Ashley (W. Camp, personal comm., 2002).

Assimaki et al. $(2000,2001)$ and Hashash and Park (2001) present models for the dynamic behavior of shear modulus and damping ratio for granular materials at higher confining pressures. These models are based on experiments performed by Laird and Stokoe (1993) to confining pressures of $5 \mathrm{MPa}$. We have adopted a modified form of the Assimaki et al. model for all materials in the study area at depths between $100 \mathrm{~m}$ and the top of the Mesozoic basement, which we assume is at $830 \mathrm{~m}$ throughout the study area. Four relationships are used, to cover the depth intervals 100-252, 252-410, 410-510, and 510-830 m. For each interval, we assume mean effective confining pressures of 


\section{Sand}
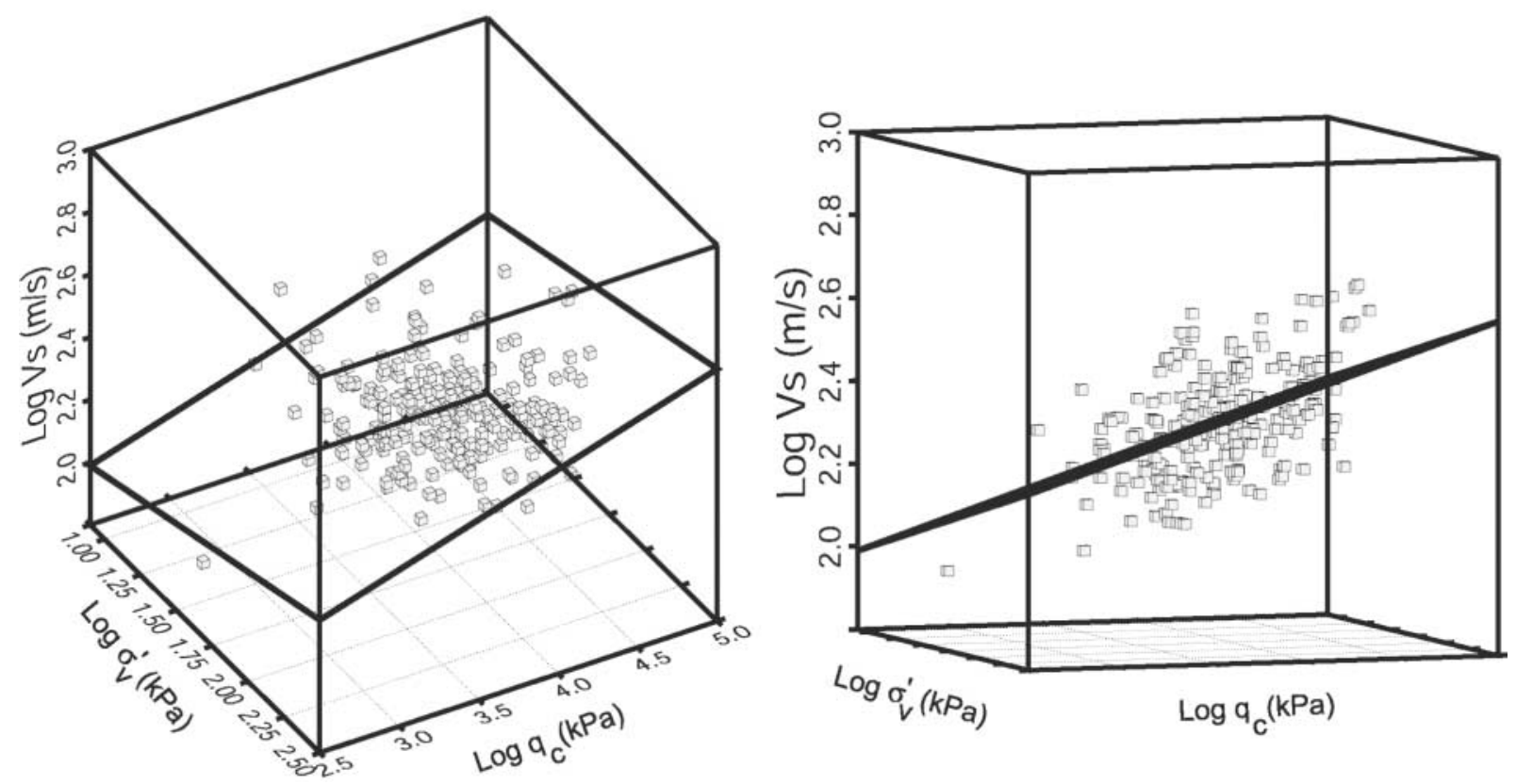

Figure 8. Regression model for sands, using data from 52 seismic cone penetrometer tests (SCPT). Measurements are indicated by the small filled cubes. The model prediction is indicated by the plane enclosed within the large cube.

\section{Clay}
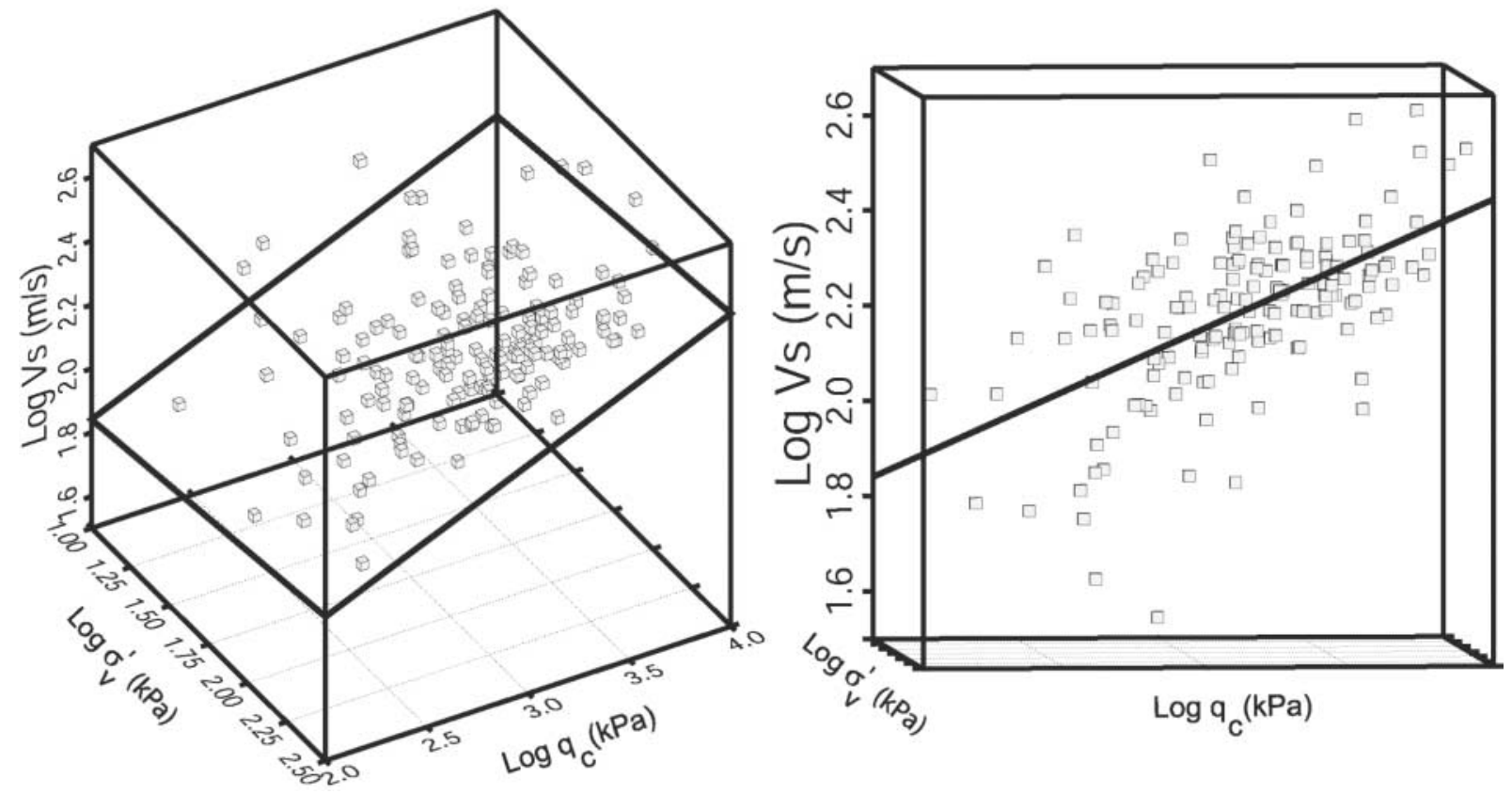

Figure 9. Regression model for clays, using data from 52 seismic SCPT investigations. Measurements are indicated by the small filled cubes. The model prediction is indicated by the plane enclosed within the large cube. 


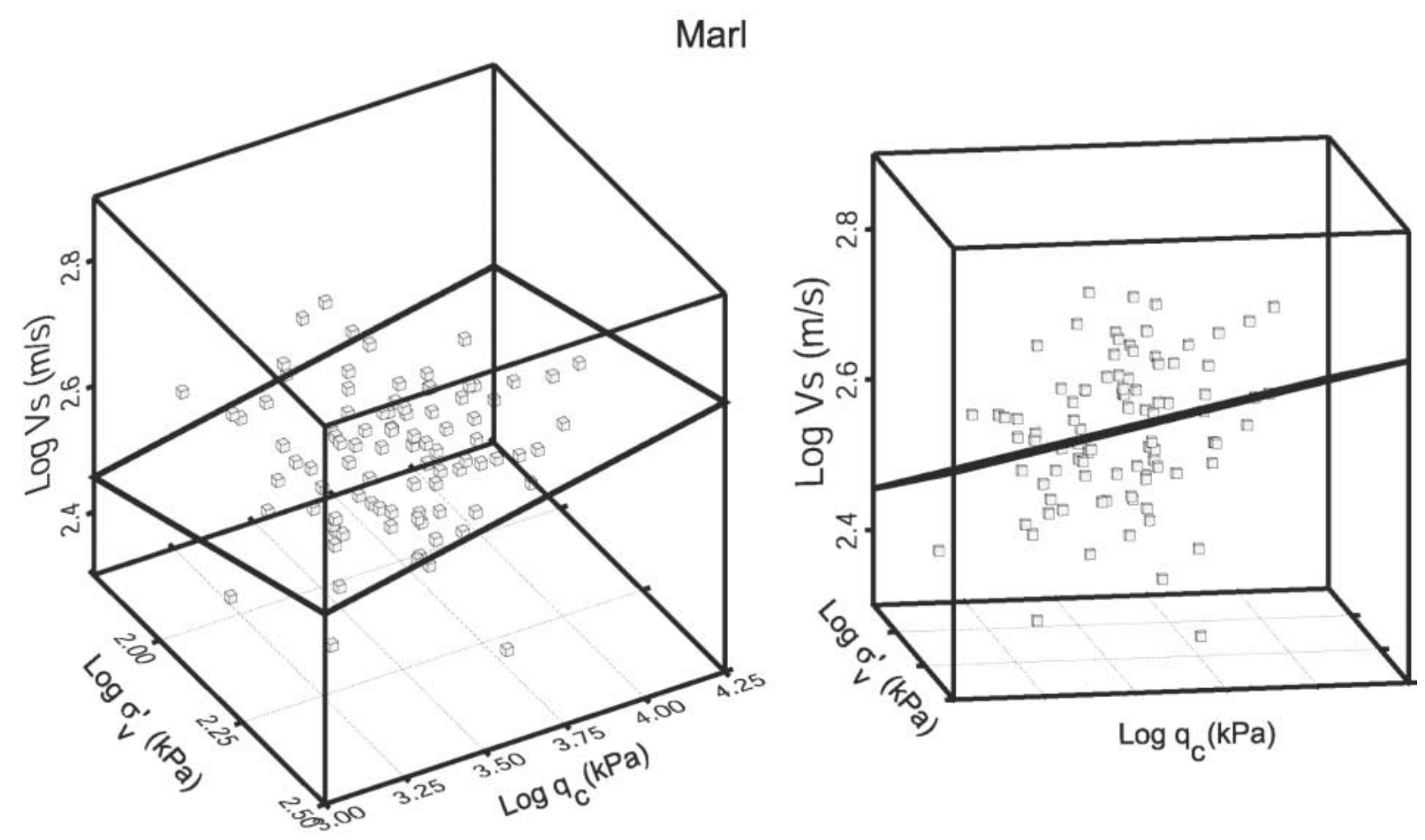

Figure 10. Regression model for Cooper marl, using data from 52 seismic SCPT investigations. Measurements are indicated by the small filled cubes. The model prediction is indicated by the plane enclosed within the large cube.

$1.15,2.16,3.04$, and $4.38 \mathrm{MPa}$, respectively. Figure 13 shows shear modulus reduction factors as a function of shear strain used for analysis. Figure 14 shows damping ratios as a function of shear strain adopted for this study.

The Assimaki et al. $(2000,2001)$ model predicts very small damping ratios for small strains when viewed in comparison with most published studies of attenuation using seismological data from earthquakes. For example, at 654 $\mathrm{kPa}$, which corresponds to a depth of approximately $100 \mathrm{~m}$, the model predicts a damping ratio of $4.7 \times 10^{-4}$ for void ratio 0.3. For comparison with seismological estimates of attenuation at infinitesimal strains, this corresponds to $Q$ of approximately 1050. Most published determinations of $Q$ in sediment deposits indicate values (for both $P$ and $S$ waves) of approximately 50 or less. For example, Boore et al. (2003) report $Q_{S}$ typically in the range 25-36 (damping, 0.0200.014) at depths less than $100 \mathrm{~m}$ for sites in California underlain by fine grained material. For greater depths, Abercrombie (1997) cites several studies in California using borehole data recorded from earthquakes that indicate $Q$ for $P$ waves less than 45 and $Q$ for shear waves less than 40 at depths greater than $100 \mathrm{~m}$. Abercrombie (1997) used a vertical array in the Cajon Pass borehole to determine $P$ and $S$ spectral ratios at various depths, with data recorded from nearby earthquakes. A 300-m-thick sedimentary section with $P$ and $S$ velocities of 1790 and $657 \mathrm{~m} / \mathrm{sec}$, respectively exhibited $Q_{S}=15$ and $Q_{P}=26$. Chapman et al. (2003) examined the spectra of microearthquakes recorded in the
Summerville-Middleton Place seismic zone approximately $25 \mathrm{~km}$ to the northwest of the study area and estimated values of the shear-wave attenuation parameter kappa in the range $0.035-0.049$, for transmission though $775 \mathrm{~m}$ of sediments. This implies "path average" $Q$ of 22-32. That estimate is consistent with the results cited previously from California and also with results by Liu et al. (1994) from similar work in the Mississippi Embayment. On the other hand, Langston (2004a, 2004b) presented an assessment of potential bias in the quantification of attenuation. On the basis of modeling microearthquake waveforms in the Mississippi Embayment, he found evidence for much higher values of $Q$ in that area.

For this analysis, we have modified the Assimaki et al. damping model by introducing a minimum damping ratio value of $5 \times 10^{-3}$ for strains less than $3 \times 10^{-5}$ as shown in Figure 13. This corresponds to a $Q$ value of 100, which is a conservative estimate when viewed in the context of most previously reported values of $Q$ in the seismological literature. This is applied at small strains to materials in the depth range 100-830 $\mathrm{m}$. The small strain damping used for the shallow Quaternary materials and the Cooper Group (also shown in Fig. 13) is approximately 0.01, corresponding to $Q$ of approximately 50. At a strain level of $1 \times 10^{-6}$ for a typical site in this study, the effective damping for the whole transmission path is approximately 0.0059 , the effective whole path $Q$ for shear waves is 85 , and the value of attenuation parameter kappa is 0.015 . 

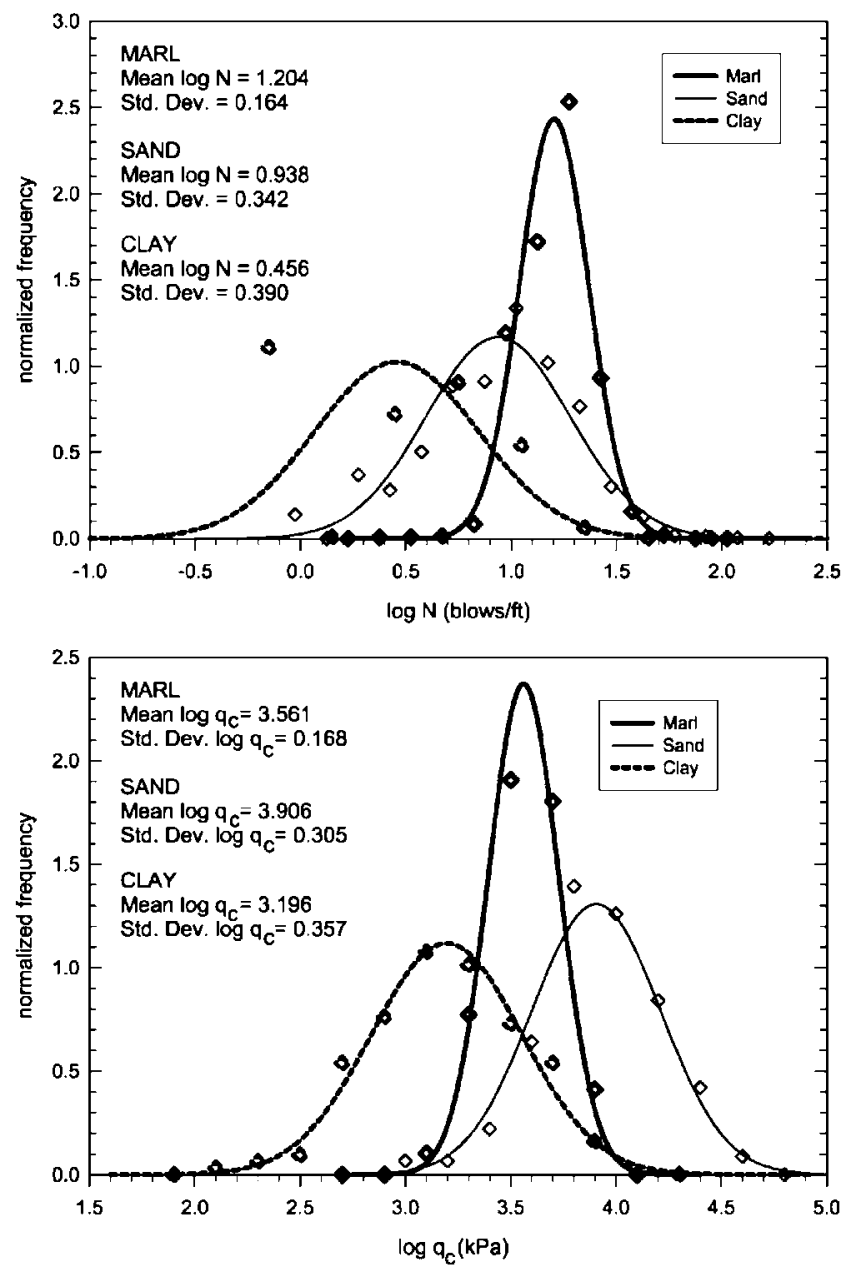

Figure 11. Distribution of SPT blowcounts $N$ (upper) and CPT tip resistance $q_{c}$ (lower).

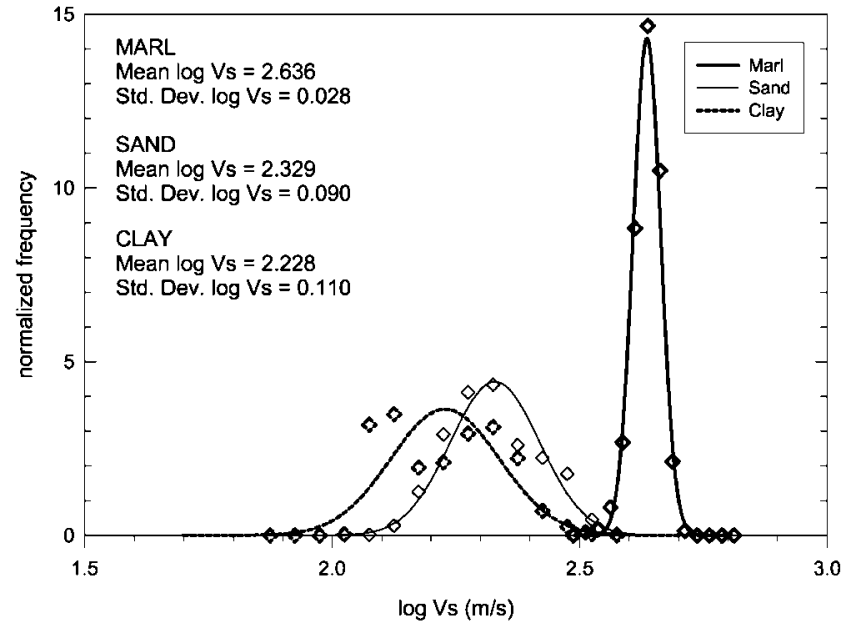

Figure 12. Shear-wave velocity $V_{S}$ indirectly inferred from standard penetration test $N$ values at 204 locations on the Charleston peninsula.

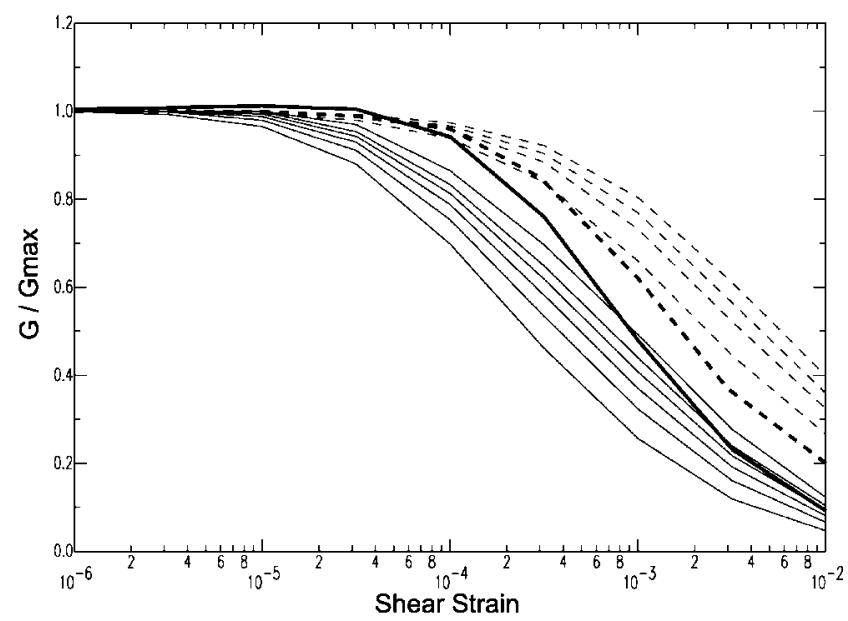

Figure 13. Shear modulus $(G)$ reduction factors as a function of shear strain. $G_{\max }$ is maximum shear modulus, at infinitesimal strain. Thin solid lines are for sands with midlayer depths of $1.5,4.5,7.5,10.5$, 13.5, and $18.3 \mathrm{~m}$ (Ishibashi and Zang, 1993). The thick solid line is the model for clay at depths less than $20 \mathrm{~m}$ (Ishibashi and Zang, 1993). The thick dashed line is for the Cooper Group, in the depth range 20-100 m (W. Camp, S\&ME, Inc., personal comm., 2002). The thin dashed lines are for materials beneath the Cooper Group, in the depth ranges 100 252, 252-410, 410-510, and 510-830 m (Assamaki et al., 2000, 2001).

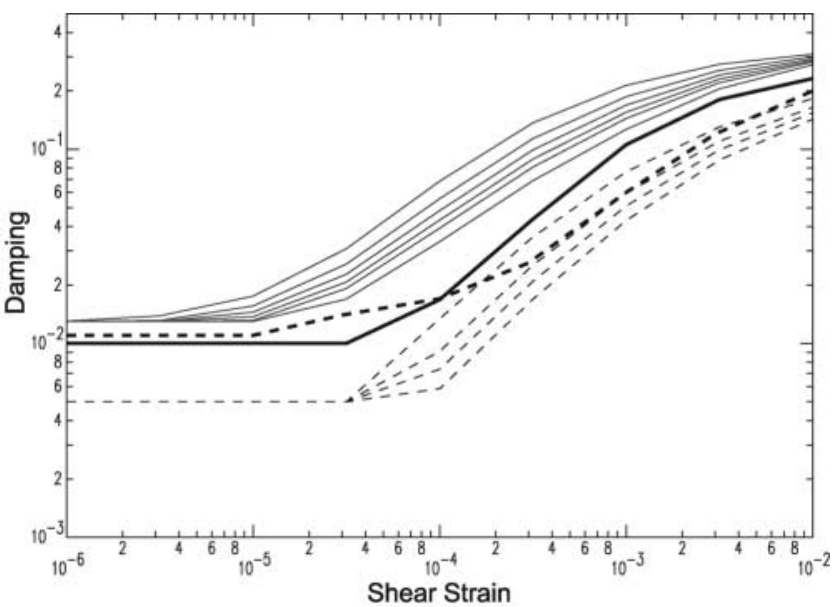

Figure 14. Material damping as a function of shear strain. Thin solid lines are for sands with midlayer depths of $1.5,4.5,7.5,10.5,13.5$, and $18.3 \mathrm{~m}$ (Ishibashi and Zang, 1993). The thick solid line is the model for clay at depths less than $20 \mathrm{~m}$ (Ishibashi and Zang, 1993). The thick dashed line is for the Cooper Group, in the depth range 20-100 m (W. Camp, S\&ME, Inc., personal comm., 2002). The thin dashed lines are for materials beneath the Cooper Group, in the depth ranges 100-252, 252-410, 410-510, and 510-830 m (adapted from Assamaki et al., 2000, 2001). 


\section{Response Estimates}

\section{Input Ground Motions}

We use five different levels of input motion intensity to model the nonlinear response of the sedimentary section in the study area. The motions are distinguished by peak acceleration values.

A point-source stochastic model (e.g., Boore, 1983; Boore and Atkinson, 1987; Atkinson and Boore, 1995) was used to simulate the outcrop motions of pre-Cretaceous basement rock. Table 2 lists the parameters of the stochastic model used to make the simulations. The scenario earthquake in all cases is at an epicentral distance of $30 \mathrm{~km}$, and at a depth of $10 \mathrm{~km}$. This scenario is consistent with a source in the area of maximum shaking intensity in 1886 , centered approximately $30 \mathrm{~km}$ to the northwest of Charleston in the vicinity of Summerville (Dutton, 1889). The motions generated for $0.1,0.2$, and $0.3 g$ peak acceleration are simulated by using moment magnitude $M 6.4,6.7$, and 7.1 , respectively. The upper range of estimates of the moment magnitude of the 1886 earthquake is 7.5 (Johnston, 1996). We used $M 7.5$ to generate the time series for the 0.4 and $0.5 \mathrm{~g}$ acceleration levels.

Twenty acceleration time series were simulated for each peak ground acceleration (PGA) level. Because PGA is a random variable, the PGA value for each realization of the stochastic model varies slightly. To ensure that the target PGA level was accurately represented, we estimated the mean PGA for the 20 simulations at each magnitude level. The 20 time series were then scaled such that the mean peak acceleration of the 20 simulations was equal to the desired mean peak acceleration value. The 20 time series were then used to develop mean estimates of the ratios of spectral acceler-

Table 2

Parameters of the Stochastic Model Used to Generate Basement Outcrop Motion for Dynamic Response Analysis

\begin{tabular}{lll}
\hline Epicentral distance: & $30 \mathrm{~km}$ & \\
Focal depth: & $10 \mathrm{~km}$ & \\
Crustal velocity: & $3.5 \mathrm{~km} / \mathrm{sec}$ & \\
Crustal density: & $2.6 \mathrm{~g} / \mathrm{cm}^{3}$ & \\
Stress parameter: & $100 \mathrm{bars}$ & \\
Crustal quality factor: & $Q=680 f^{0.36}$ & \\
Free surface factor: & 2.0 & \\
Radiation pattern: & 0.55 & \\
Component partition factor: & 0.707 & \\
\hline \multicolumn{1}{c}{ Moment Magnitude } & Mean PGA* $(g)$ & Scaling Factor \\
\hline \multicolumn{1}{c}{0.4} & 0.169 & 0.591 for $0.1 g$ \\
6.7 & 0.218 & 0.917 for $0.2 g$ \\
7.1 & 0.300 & 1.000 for $0.3 g$ \\
7.5 & 0.436 & 0.917 for $0.4 g$ \\
7.5 & 0.436 & 1.147 for $0.5 g$ \\
7.5 & 0.436 & 1.376 for $0.6 g$ \\
\hline
\end{tabular}

\footnotetext{
* Mean PGA from 20 realizations of the stochastic model.

${ }^{\dagger}$ Scaling factor applied to each of 20 simulations for use in response analysis.
}

ation (SA) response on the ground surface to that of the SA response on an outcrop of the basement rock at each study site.

\section{Site Conditions and General Site-Response} Characteristics

The 52 seismic cone penetrometer tests provide the data used for dynamic analysis. To examine these velocity data for any obvious correlation with surface geology, we have calculated average velocity of material above the interpreted depth of the top of the Copper Group, or "top of marl." Figure 15 shows these values, plotted versus the depth to the top of marl. Different symbols are used in Figure 15 to indicate different mapped geological units, shown in Figure 1. The average velocity here is determined by summing the vertical shear-wave travel times of each Quaternary layer interpreted in the SCPT profiles, and then dividing that sum by the sum of the layer thicknesses. Inversion of the result gives a measure of the shear-wave velocity for the entire sequence.

Figure 15 shows no obvious correlation of mean Quaternary material velocity with mapped surface geological unit. The four measures of velocity on artificial fill are all less than $200 \mathrm{~m} / \mathrm{sec}$, but otherwise the lack of geological correlation of these average velocity data suggests that mapped surface geology does not provide an easily inter-

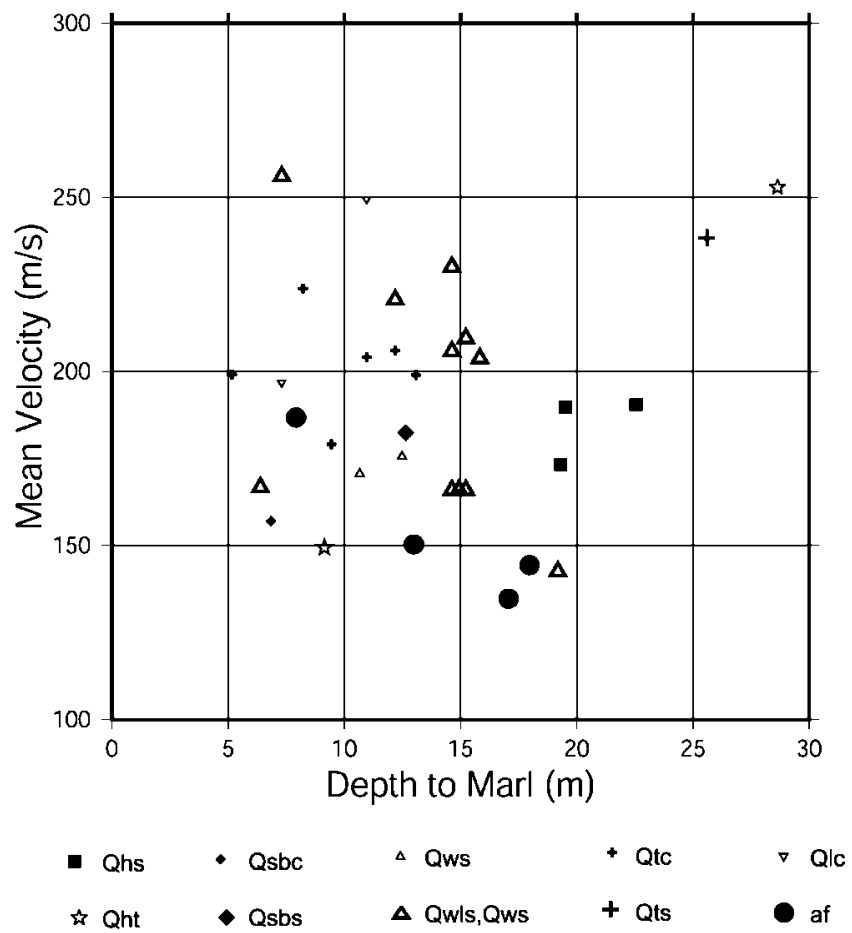

Figure 15. Average shear-wave velocity of Quaternary sediments above the Tertiary Cooper Group (Cooper marl), derived from seismic cone penetrometer tests. Symbols refer to geological units mapped in Figure 1 and described in Table 1. 
preted diagnostic for potential variation of mean Quaternary material velocity. Although the measured shear-wave velocity data set is very small for most of the individual units, the velocities for the Quaternary as a whole appear to cluster tightly about a central value of $200 \mathrm{~m} / \mathrm{sec}$, suggesting that as a whole, the sediments are relatively uniform in terms of shear moduli.

The small range of variation of mean velocity $( \pm 50$ $\mathrm{m} / \mathrm{sec}$ ) about a central value of $200 \mathrm{~m} / \mathrm{sec}$ has implications for site-response prediction. The vertical time of shear-wave propagation through the Quaternary section at these sites depends largely on the variable thickness of the section because the site-to-site variation of velocity in the Quaternary sediments is small. For example, Figure 15 shows that this thickness varies between about 5 and $30 \mathrm{~m}$ for the 52 SCPT sites with measured shear-wave velocity data.

Although there is no clear correlation of Quaternary average velocity and mapped surface geology based on the the 52 seismic cone penetrometer tests, there is a correlation of depth to the Tertiary units (marl) and mapped surface geology. In general, Tertiary units are near the surface in the northern and northwestern parts of the study area and are exposed in stream banks in those areas. The Tertiary units lie at greater depths beneath the progressively younger beach terrace complexes that roughly parallel the coastline. Hence, Quaternary sediments of the Ladson formation (Qlc) are relatively thin in the northwestern section of the study area, whereas sites on the younger Ten Mile Hill beds typically overlie a somewhat deeper Tertiary-Quaternary contact, and sites in the Wando, Silver Bluff, and modern terrace complex, in general, overlie the Tertiary units at still greater depths. Although depth to Tertiary is correlated with the age of the surface deposits, this correlation is weak because the TertiaryQuaternary contact is an irregular surface. Depth to that surface depends on ground surface elevation, as well as the complex erosion and depositional history of the study area.

Figure 16 is based on the entire data set shown in Figure 1, representing more than 230 geotechnical investigations. It shows that the depth to the marl is less than $15 \mathrm{~m}$ at most of the sampled sites in the Ladson and Ten Mile Hill surface exposure areas. Several of those sites exhibit depth to marl of less than $10 \mathrm{~m}$. Depth to marl at sites closer to the coast, on the younger Wando, Silver Bluff, and modern beach terrace complex typically exceeds $14 \mathrm{~m}$. Depth to marl exceeds $20 \mathrm{~m}$ at several sites in downtown Charleston on Wando and Silver Bluff sand units Qws and Qsbs. Because the beach and barrier island deposits tend to form the highest ground surface elevations in the study area, depth to marl in general is largest under areas where beach sand units (e.g., Qws, Qsbs) are mapped at the surface.

The contrast in velocity between the Quaternary and Tertiary units in the study area is substantial. Figure 17 plots the SCPT shear-wave velocities for the Tertiary units. The velocities of the "Cooper marl" average approximately 400 $\mathrm{m} / \mathrm{sec}$, with most measurements in the range $300-500 \mathrm{~m} / \mathrm{sec}$. As a result, we can expect that for an average site in the
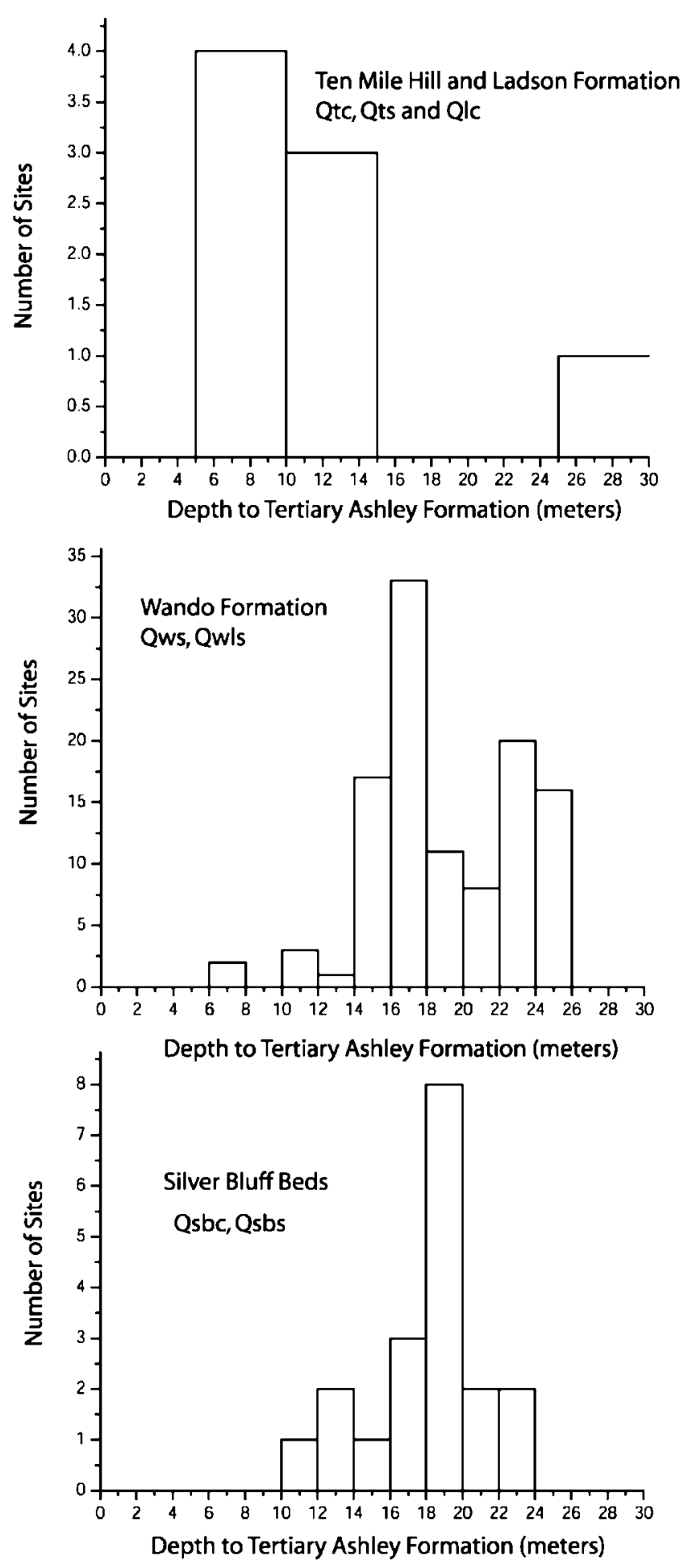

Figure 16. Distributions of depths to the Quaternary-Tertiary boundary, grouped by mapped surface geological units (refer to Fig. 1 and Table 1 for geologic map and description of units). 
study area, the Quaternary-Tertiary impedance contrast will typically be about 2 , based on mean velocities of 400 and $200 \mathrm{~m} / \mathrm{sec}$, for the uppermost Tertiary units (Cooper marl) and Quaternary material at the SCPT sites.

Figure 18 shows estimates of layer-over-half-space fundamental resonance frequency for vertically incident shear waves for the SCPT sites. Site fundamental frequency is given by $V^{\prime} / 4 h$, where $h$ is depth to marl and $V^{\prime}$ is average shear-wave velocity of the Quaternary section. The curve is constructed for $V^{\prime}=200 \mathrm{~m} / \mathrm{sec}$. Various symbols refer to mapped geological units shown in Figure 1 and described in Table 1.

The results in Figure 18, based on direct measurement of shear-wave velocity in the subsurface at each of the plotted sites, indicate that site-resonance frequency largely depends on the depth to the Tertiary Cooper Group. The small amount of scatter about the line in Figure 18 is due to the small variability $( \pm 50 \mathrm{~m} / \mathrm{sec})$ of average velocity in the Quaternary section. The estimated fundamental resonance frequency at these 52 investigated sites is controlled by the depth to the Tertiary (Cooper Group, Ashley formation). Because of spatially complex erosion and depositional processes, the depth to Tertiary varies considerably in the study area from 5 to approximately $30 \mathrm{~m}$ at the sites examined. In general, we expect ground-motion amplification of about a factor of 2 because of the velocity contrast between Tertiary and Quaternary units. Because of the variability of thickness of the Quaternary units, this amplification will occur at various frequencies between 2 and $10 \mathrm{~Hz}$.

Another important geological characteristic that is common to all sites in the study area is the major impedance contrast at the base of the Coastal Plain sedimentary section. This occurs at a depth of about $800-900 \mathrm{~m}$ in the study area. As shown in Figure 6, we model the Pre-Cretaceous basement rock with shear-wave velocity of $3.45 \mathrm{~km} / \mathrm{sec}$ (density, $2600 \mathrm{~kg} / \mathrm{m}^{3}$ ), and the overlying Cretaceous sediments with velocity $822 \mathrm{~km} / \mathrm{sec}$ (density, $2000 \mathrm{~kg} / \mathrm{m}^{3}$ ) inferred from a $P$-wave velocity $\log$ at the Clubhouse crossroads well and travel times of converted phases in the nearby Middleton Place seismic zone (Chapman et al., 2003). This results in an impedance contrast of 5.46. This is the largest impedance contrast modeled along the path from earthquake source to ground surface in the study area and has a major effect on the predicted response.

Figure 19 is constructed to illustrate the two main geological effects on modeled site response. These are (1) the impedance contrast and single-layer effect of the entire Coastal Plain sequence and (2) the impedance contrast and single-layer effect of the Quaternary sequence. Figure 19 shows the response of a single layer over half-space model representing the entire coastal plain sequence, where the impedance contrast is 5.46 and the vertical traveltime is 1.25 sec. Also shown is a single-layer response for a impedance contrast of 2.0 and vertical travel time of $0.075 \mathrm{sec}$. This is a rough approximation of the individual response (surfacemotion amplitude spectrum divided by amplitude spectrum

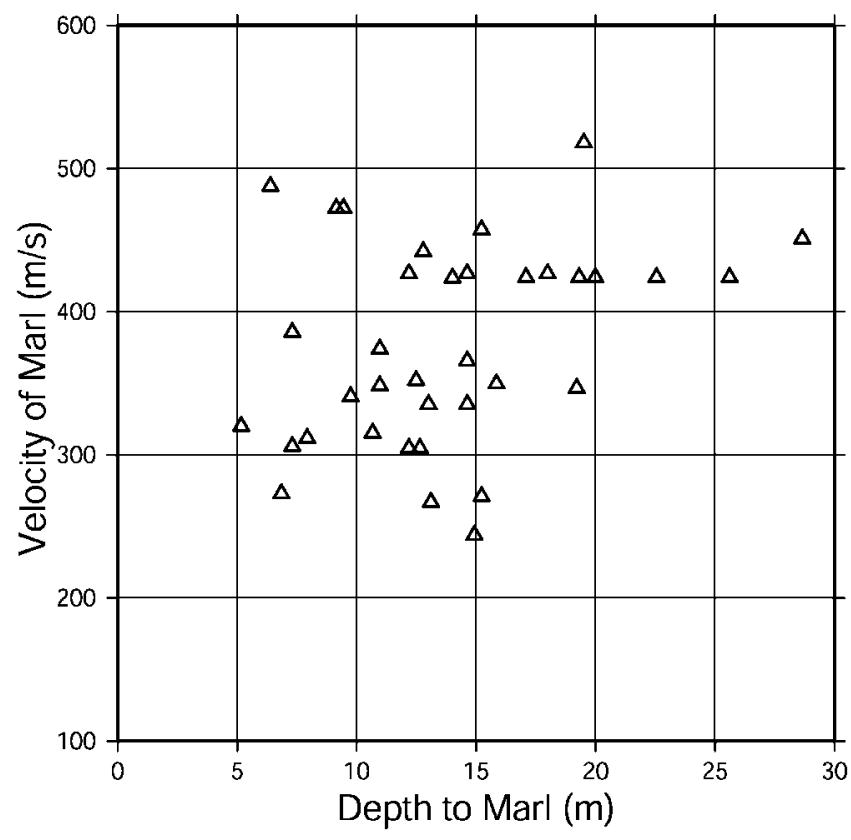

Figure 17. Shear-wave velocity measurements of material immediately below the top of the Tertiary Cooper Group (Cooper marl), derived from seismic cone penetrometer tests.

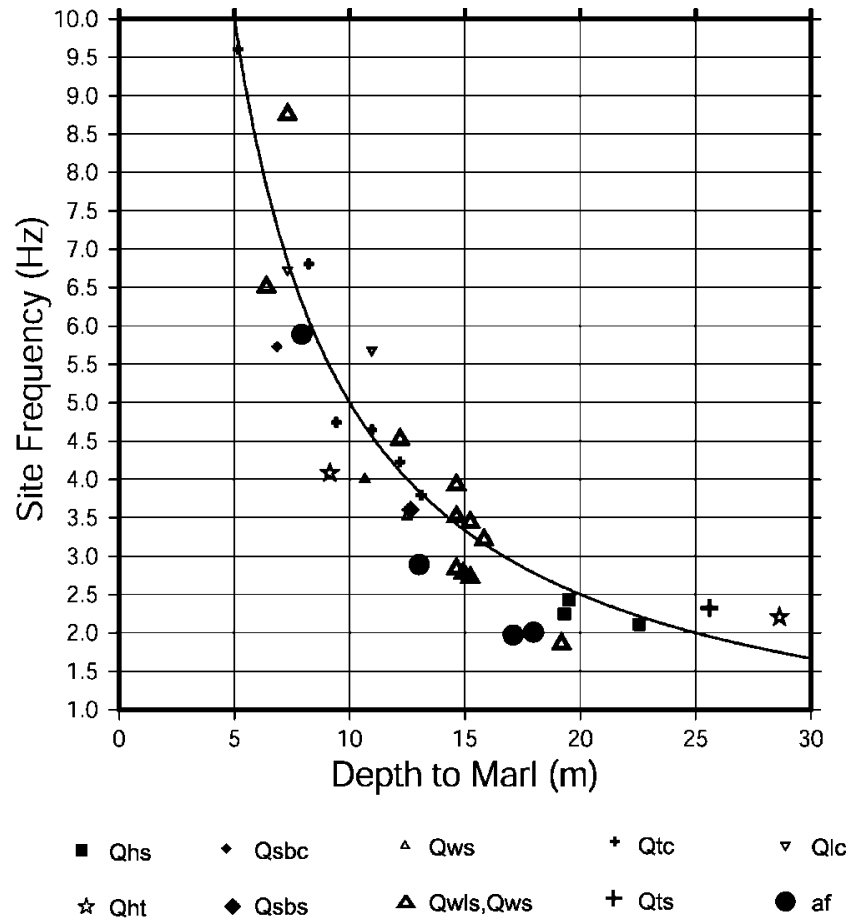

Figure 18. Fundamental resonance frequency for a single layer over half-space for vertically incident shear waves. The symbols refer to different geological units shown in Figure 15. The curve is constructed for $V^{\prime}=200 \mathrm{~m} / \mathrm{sec}$. 
of half-space outcrop motion) due to the total Coastal Plain section and the Quaternary section, respectively. The responses shown in Figure 19 are for linear behavior and quality factors $Q=100$. Also shown in Figure 19 is the combined effect of both response functions, which models to a first approximation the major features of estimated site response in the Charleston area.

Figure 19 illustrates, in simplified form, that the two main geological features produce very distinctive site-response features. The effect of the entire Coastal Plain sequence is to introduce site amplifications at frequencies of approximately $0.2,0.6,1.0,1.4,1.8$, etc., or at odd harmonics of $1 / 4 T$, where $T$ is the one-way shear-wave travel time of approximately $1.25 \mathrm{sec}$ through the section. The effect of the Quaternary section is due to the same physical process, but resonance frequencies occur, as modeled in this example, at frequencies of 3.3, 9.9, $16.5 \ldots \mathrm{Hz}$, due to the much smaller travel time of shear waves through that sequence. The combined effect of the two layers is also shown in Figure 19.

\section{Results}

The results of this study are in the form of 5\% damped SA response spectral ratios for the ground surface motion to that of an outcrop of hard (Pre-Cretaceous) basement rock. The calculations incorporate much more detail than the simple examples shown in Figure 19 and involve as many as 30 different layers for some sites. In each case, we take into account nonlinear behavior of the sediments, so that the computed responses depend on the peak acceleration levels of the input motions. However, in most cases, the general characteristics of site response shown in Figure 19 can be recognized in the results derived for the individual sites, regardless of site location and input motion level.

Figure 20 plots the SA spectral ratios for the 52 SCPT sites, for input motions of $0.1,0.3$, and $0.5 \mathrm{~g}$. Note that the spectral ratios of the various sites are similar at the lowest frequencies $(0.2 \mathrm{~Hz})$ and that they diverge with increasing frequency to a maximum dispersion amounting to about a factor of 3 at approximately $5 \mathrm{~Hz}$. The frequency band 1 to approximately $10 \mathrm{~Hz}$ corresponds to the band in which the difference in site response due to variability of the Quaternary section thickness, and to a lesser degree, the velocity layering within that sequence, is most important. At higher frequencies (greater than $10 \mathrm{~Hz}$ ), the SA spectral ratios at these sites converge to within a factor of 2 at $30 \mathrm{~Hz}$. At the low frequencies, the estimated response ratios exhibit spectral modulation corresponding to the first few harmonics of the total Coastal Plain sequence $(0.2,0.6$, and $1.0 \mathrm{~Hz})$, an effect that we have modeled as common to all the sites in the study area. The observation of low-frequency spectral peaks analogous to those predicted here has been reported for the geologically similar Mississippi Embayment by Bodin and Horton (1999) on the basis of broadband H/V microtremor analysis.

For $0.1 \mathrm{~g}$ input motion amplitude, the maximum median
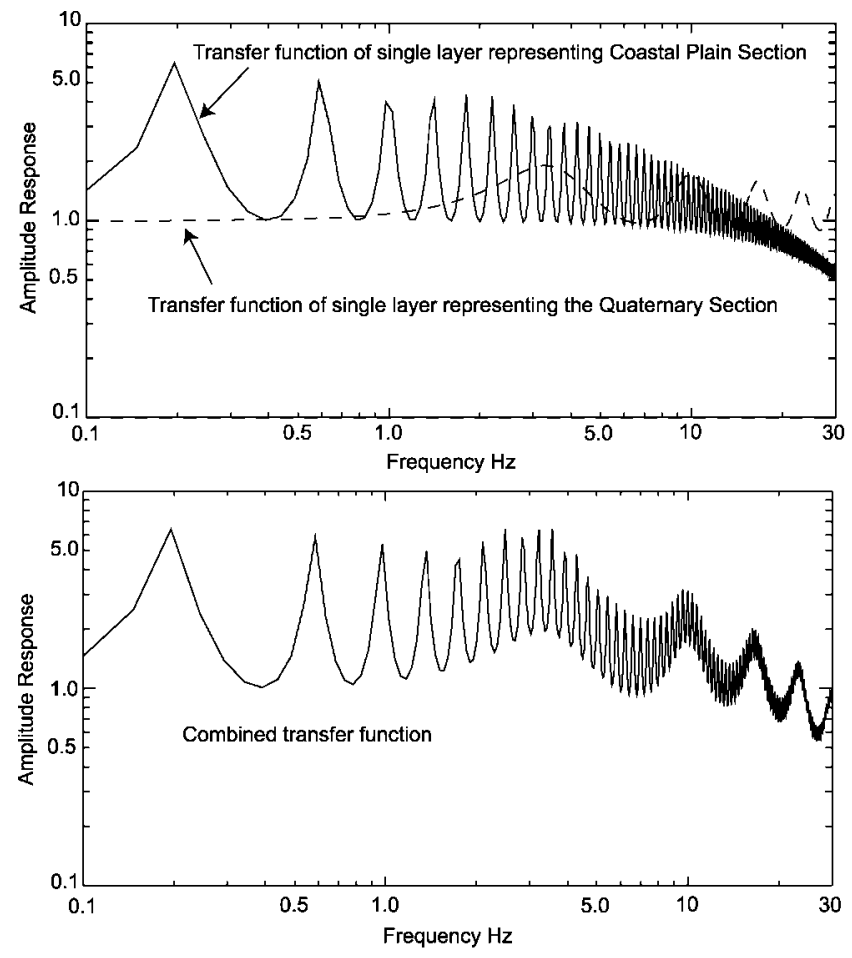

Figure 19. The upper plot shows the Fourier amplitude spectra of single-layer-over-half-space transfer functions representing the total Coastal Plain section (solid line) and the Quaternary section (dashed line). The lower plot shows the combined effect of both geological features on the Fourier amplitude spectrum of site response. The figure is a gross simplification of the response at any specific site.

response is 4.0 and occurs in the frequency range from 1 to $3 \mathrm{~Hz}$. The site conditions in the study area amplify $0.1 \mathrm{~g}$ PGA input motion in the frequency band from 0.2 to $10 \mathrm{~Hz}$ at almost all sites. As the input motion amplitude increases, the frequency band in which amplification occurs narrows, and the high frequency motions become attenuated. For example, at $10 \mathrm{~Hz}$, the median response for $0.1 \mathrm{~g}$ input motion is 1.5 , for $0.3 \mathrm{~g}$ it is 0.65 , and for $0.5 \mathrm{~g}$, the median response is 0.41 . The results shown in Figure 20 are in good agreement with previously developed results by Silva et al. (2003) for the Charleston area.

Importance of the Depth to the Quaternary-

Tertiary Boundary

Systematic differences in estimated site response are apparent when the sites are grouped according to depth of the Quaternary-Tertiary contact (Fig. 21). For example, given $0.1 g$ input excitation, sites with a thickness of Quaternary section exceeding $15 \mathrm{~m}$ exhibit the largest response in the frequency band 0.8 to approximately $3 \mathrm{~Hz}$. On the other hand, sites with less than $15 \mathrm{~m}$ of soft Quaternary material exhibit the highest amplifications at the higher frequencies (e.g., $>4 \mathrm{~Hz}$ for $0.1 \mathrm{~g}$ input). The depth to the Quaternary- 

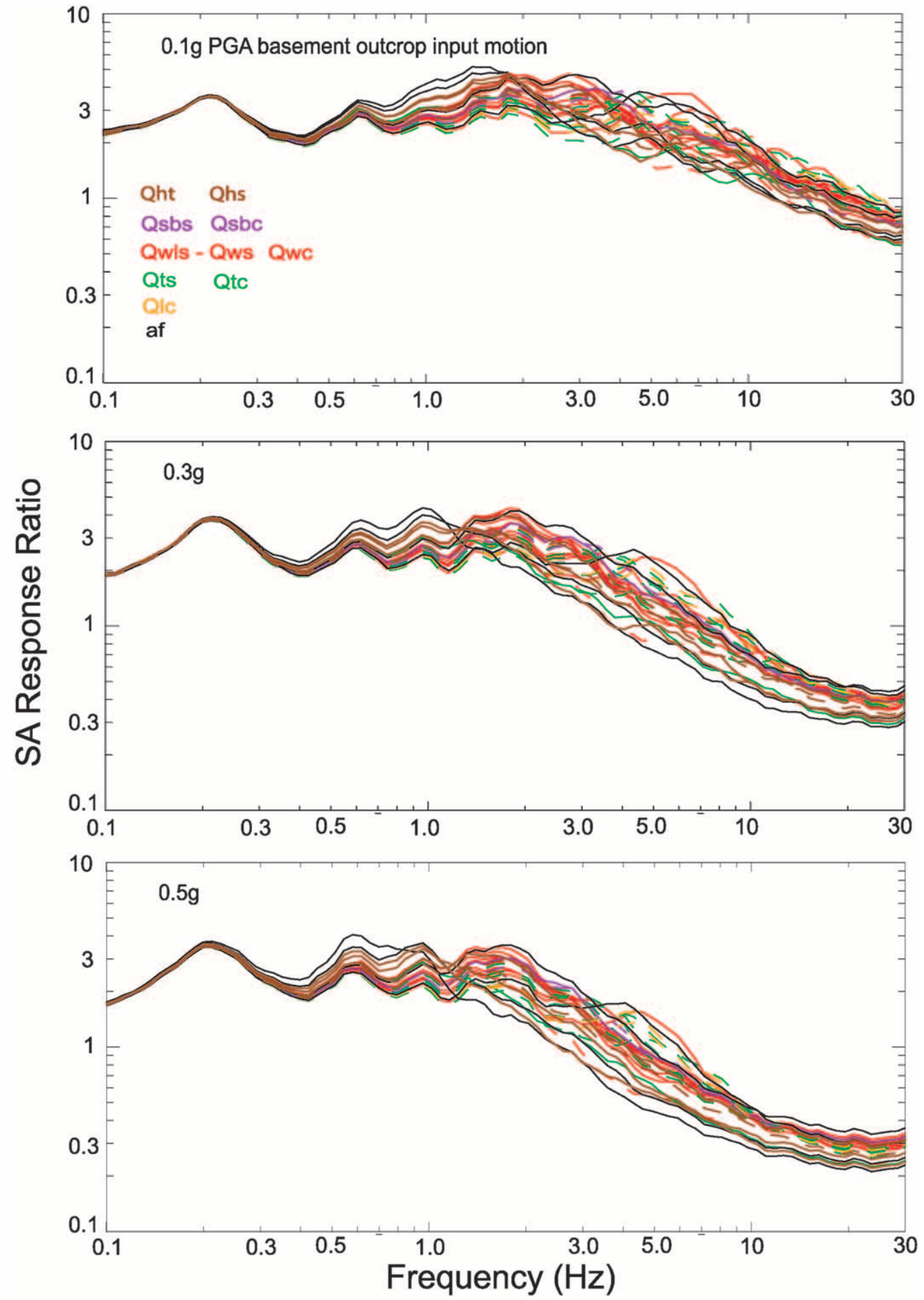

Figure 20. SA response spectral ratios (ground surface divided by basement rock outcrop) for $0.1 \mathrm{~g}, 0.3 \mathrm{~g}$, and $0.5 \mathrm{~g}$ peak acceleration basement rock outcrop input motions. The different colors refer to sites on different geological units, described in Table 1. Results from 52 locations with shear-wave velocity determinations by seismic cone penetration testing are shown. 
Tertiary impedance contrast is, on the basis of these calculations, the most important accessible parameter for characterizing the site response in the Charleston area. This is inferred from a comparison of the median site response for each of four depth range groupings, shown on the left side of Figure 21, with the distribution of responses for the ungrouped data, shown of the right side of Figure 21. Most of the variance of the ungrouped responses (represented by the 15-85 percentile interval) is accounted for by the dispersion of the median responses of the individual depth range groupings.

\section{Site Response and $V_{30}$}

Figure 22 plots the estimated SA response ratio (ground surface divided by basement outcrop) for all 281 sites in the study versus $V_{30}$. In estimating $V_{30}$, we have assumed that the shear-wave velocities in the Tertiary Cooper Group are those measured on the suspension log at the Cooper River Bridge (main pier). The results show that the behavior of the modeled response ratios is correlated with $V_{30}$. The correlation is negative (i.e., the SA ratio decreases with increasing $V_{30}$ ) at lower oscillator frequencies, as shown for 1- $\mathrm{Hz} \mathrm{SA}$ on the left side of Figure 22. This negative correlation is consistent with the findings of many previous studies (for a summary, see Boore, 2004). However, as shown on the right side of Figure 22 for $5-\mathrm{Hz} \mathrm{SA}$, this correlation is positive at higher frequencies for the sites modeled in this study. This complex behavior results because (1) the velocities of the Quaternary sediments are similar at the different sites, (2) the impedance contrast between the Quaternary and Tertiary sediments is large (a factor of approximately 2 , on average), and (3) the depth to the large Quaternary and Tertiary impedance contrast is highly variable at the different sites but lies within the interval used to determine $V_{30}(30 \mathrm{~m})$. Our modeling of the Charleston area suggests that siteresponse ratios for oscillator frequencies exceeding approximately $4 \mathrm{~Hz}$ may be larger (for a given input motion level) on sites with higher $V_{30}$ values: these sites tend to be those where the depth to marl is small. The transition from negative to positive correlation of SA response ratio and $V_{30}$ for this data set occurs in the frequency range approximately 2$4 \mathrm{~Hz}$, as can be discerned from Figure 21, where the median response ratios for sites with shallow depth to marl cross the curves for sites on thicker sections of Quaternary sediment.

\section{Sensitivity of Results to Uncertainty of Velocity in the Deeper Coastal Plain Sediments}

The study focus is on the response effects due to geological conditions at shallow depths, where geotechnical investigations have been conducted. The results described above are based on very sparse information concerning shear-wave velocity and material dynamic properties of the deeper Coastal Plain sediments. The results illustrated in Figures 20 and 21 indicate the nature of site response under the assumption that our best-estimate model for the deeper materials (greater that approximately $100 \mathrm{~m}$ ) is accurate, and spatially invariant across the study area. The degree to which this assumption may hold cannot be tested until such time as data bearing upon the question are collected.

We have attempted to assess the sensitivity of the modeling results to uncertainty of shear-wave velocity in the deeper Tertiary and Cretaceous sediments that lack direct shear-wave velocity measurement. This was done by computing site response for a typical site in Charleston based on 200 realizations of a model wherein the velocities at depths indicated in Figure 6 as zones B, C, D, E, and F are treated as independent, random variables.

We divided each layer of the model shown in Figure 6 into five sublayers. The velocity of each sublayer was assumed to be log-normally distributed, with median velocity as shown in Figure 6. The standard deviation of the natural logarithm of the velocity for each sublayer was taken to be 0.345 , based on the distribution of layer velocities indicated in Figures 4 and 6, which are derived from $S$-wave velocity measurements in the upper $100 \mathrm{~m}$ at the bridge sites and the sonic log from the Clubhouse Crossroads no. 1 well. The thickness of the sublayers was held constant and the velocities of adjacent sublayers are assumed to be independent. Figure 23 shows the resulting velocity distribution.

Figure 24 summarizes the results of the sensitivity analysis. Plotted in Figure 24a are the 15th, 50th, and 85th percentiles of the SA response ratio for $0.1 \mathrm{~g}, 0.3 \mathrm{~g}$, and $0.5 \mathrm{~g}$ peak acceleration input motion at a single site using the (constant) measured velocity profile in zone A and the randomized velocity model for zones B through $\mathrm{F}$. The range of dispersion for each of the three levels of excitation at this site is quantified as the ratio of the 85th percentile value to that of the 50th percentile (median) value, and plotted in Figure $24 \mathrm{~b}$. We observe that in the $1-$ to $10-\mathrm{Hz}$ range, the $85 / 50$ percentile ratio is approximately 1.2 for $0.1 \mathrm{~g}$ excitation, $1.4-1.5$ for $0.3 g$ excitation, and $1.3-1.9$ for $0.5 g$ excitation.

We can compare the levels of dispersion due to randomization of the deep sediment velocities (that were generated by using a single site with fixed shallow velocity structure) with that of the modeling results for all 52 SCPT sites that were determined by using the (fixed) median velocity model for the deep sediments. The dashed lines in Figure 24b show that the $85 / 50$ percentile ratios for the 52 SCPT sites (taken from the curves shown on the right side of Figure 21). The ratios lie in the range 1.1 to 1.4 in the 1.0 to $10-\mathrm{Hz}$ frequency band. We note that the variability of calculated response due to our model of velocity uncertainty in the TertiaryCretaceous section is similar to that due to shallow geological variability (primarily involving the thickness of the Quaternary) for $0.1 \mathrm{~g}$ excitation levels. At higher levels of input motion $(0.3 g, 0.5 g)$, the variability due to randomization of the deep sediment velocity is somewhat larger than that due to shallow geological differences among the 52 sites examined with the SCPT method. 


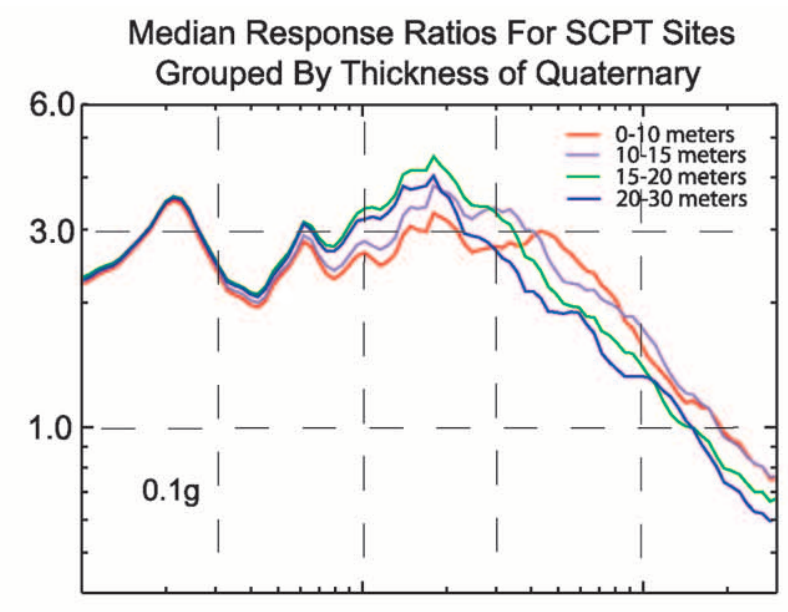

\section{5, 50 and 85 Percentile Response Ratios For All SCPT Sites}
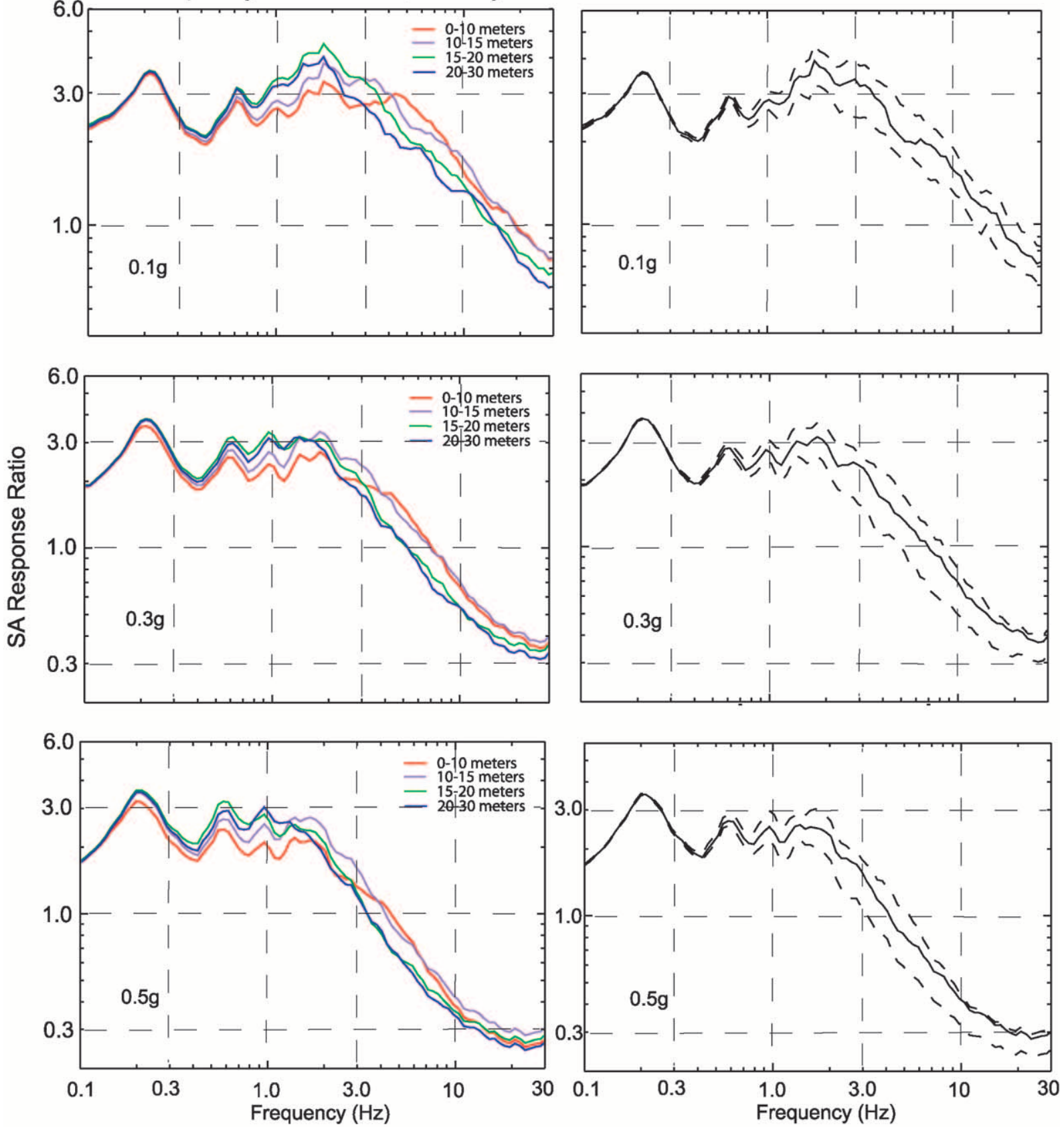

Figure 21. (Left) Median SA response ratios at 52 sites with shear-wave velocity measurements determined by seismic cone penetration tests grouped according to thickness of Quaternary sediments. Red, 0-10 m, purple, 10-15 m, green, 15-20 m, blue, 20-30 m. (Right) 15th (dashed line), 50th (solid line), and 85th (dashed line) percentile response ratios for all 52 sites with measured shear-wave velocities. Results for $0.1 \mathrm{~g}$ (top), $0.3 g$ (middle), and $0.5 g$ PGA input motion are shown.

\section{Conclusions}

This study has focused on modeling the site-response effects due to near-surface geology in an area where instrumental recordings of both strong- and weak-motion data for direct assessment of site response are lacking. We have used measured shear-wave velocities at shallow depths and the results of CPT and SPT geotechnical methods to develop models for dynamic site-response analysis and use those models in conjunction with stochastic simulations of scenario earthquake ground motion to assess the main features of site response. 

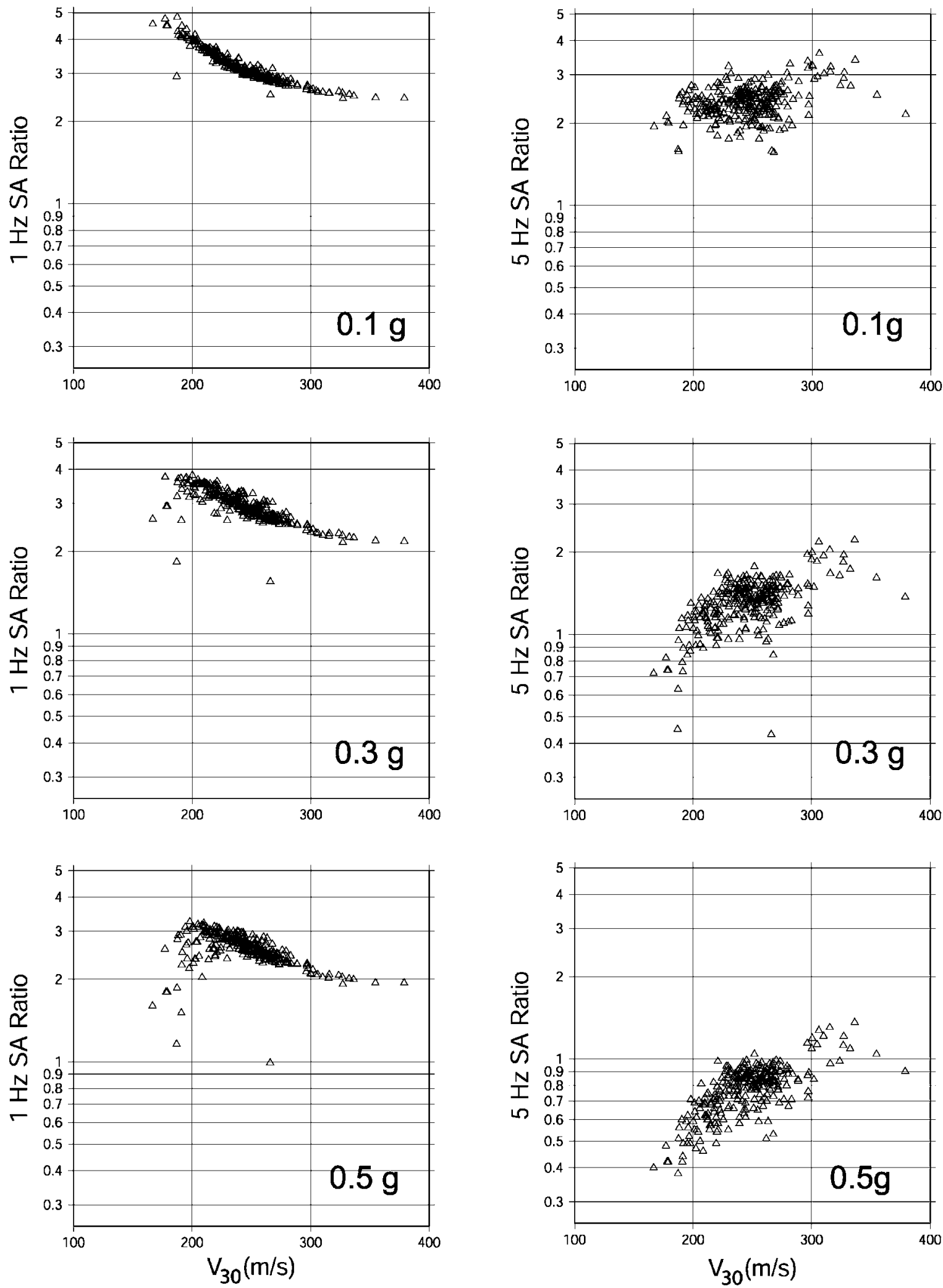

Figure 22. Modeled SA response ratios at 281 study sites (ground surface divided by basement rock outcrop) versus average velocity in the upper $30 \mathrm{~m}$ for $1 \mathrm{~Hz}$ (left) and $5 \mathrm{~Hz}$ (right). The plots are constructed for basement rock outcrop input motion of $0.1 g$ (top), $0.3 g$ (middle), and $0.5 g$ (bottom) PGA. 


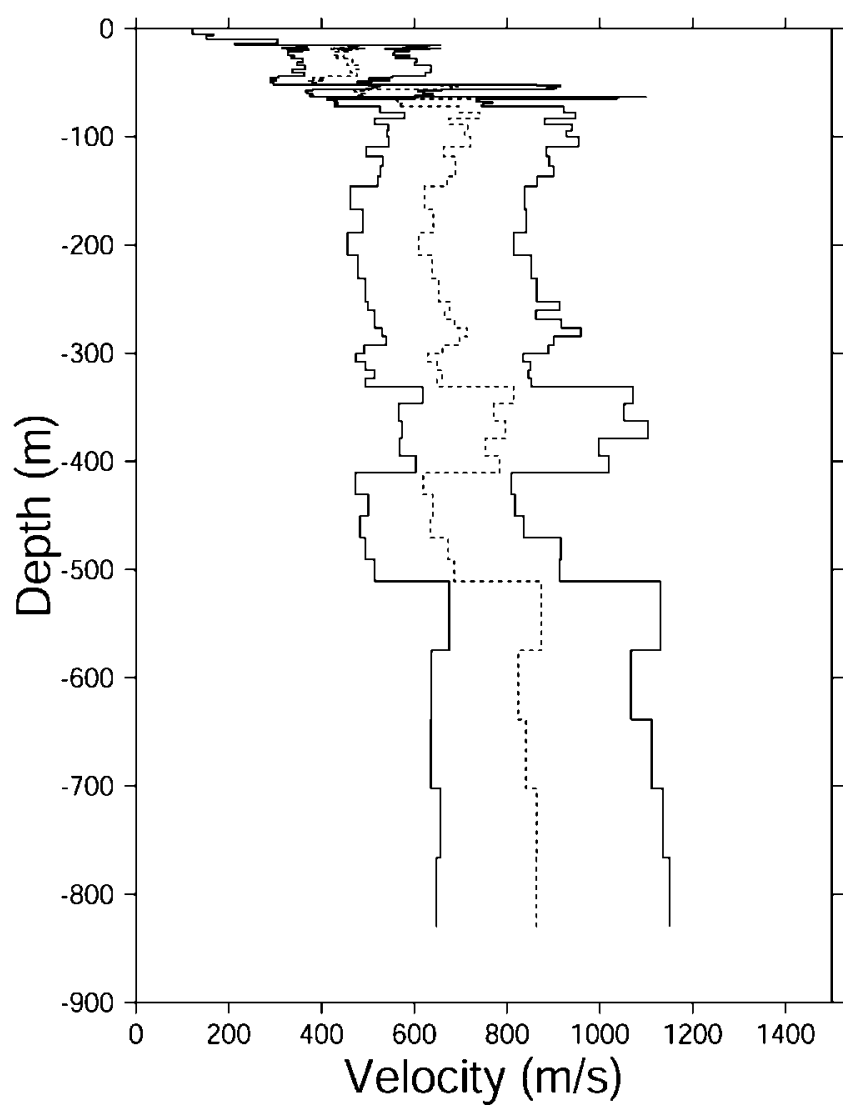

Figure 23. Randomized velocity model for Tertiary and Cretaceous units. The median velocity is indicated as the dashed line. Solid lines indicate 15th and 85 th percentile velocity values.

Our conclusions are based on investigations at 52 sites with measured shear-wave velocity at shallow depth and indicate that median SA response amplification at those sites in the 1.0 - to $10-\mathrm{Hz}$ band reaches 4.0 (at $2.0 \mathrm{~Hz}$ ) for $0.1 \mathrm{~g}$ PGA input motion, 3.0 (at $2.0 \mathrm{~Hz}$ ) for $0.3 \mathrm{~g}$ input, and 2.5 (at $1.2 \mathrm{~Hz}$ ) for $0.5 \mathrm{~g}$ input. Ground motions are amplified at frequencies less than $20 \mathrm{~Hz}$ for $0.1 \mathrm{~g}$ input motion. However, the bandwidth of amplification decreases with increasing levels of input motion amplitude because of our modeling of nonlinear effects, so that deamplification of SA response occurs at frequencies greater than approximately 10 and $6 \mathrm{~Hz}$, for 0.3 and $0.5 \mathrm{~g}$ PGA input levels, respectively. We caution that the site responses estimated for the highest amplitude input motions $(0.5 \mathrm{~g})$ are very dependent on the specific shear modulus and material damping versus strain models used here for the deeper Coastal Plain sediments, which in turn are uncertain. Also, the results at the highest strain level $(0.5 g)$ depend on the formulation of the calculations. We have used the "equivalent-linear" approach (Schnabel et al., 1972), which has been demonstrated to overdamp the response compared with nonlinear formulations at high strain levels (Hartzell et al., 2004).

Two geological features control the results of our mod-

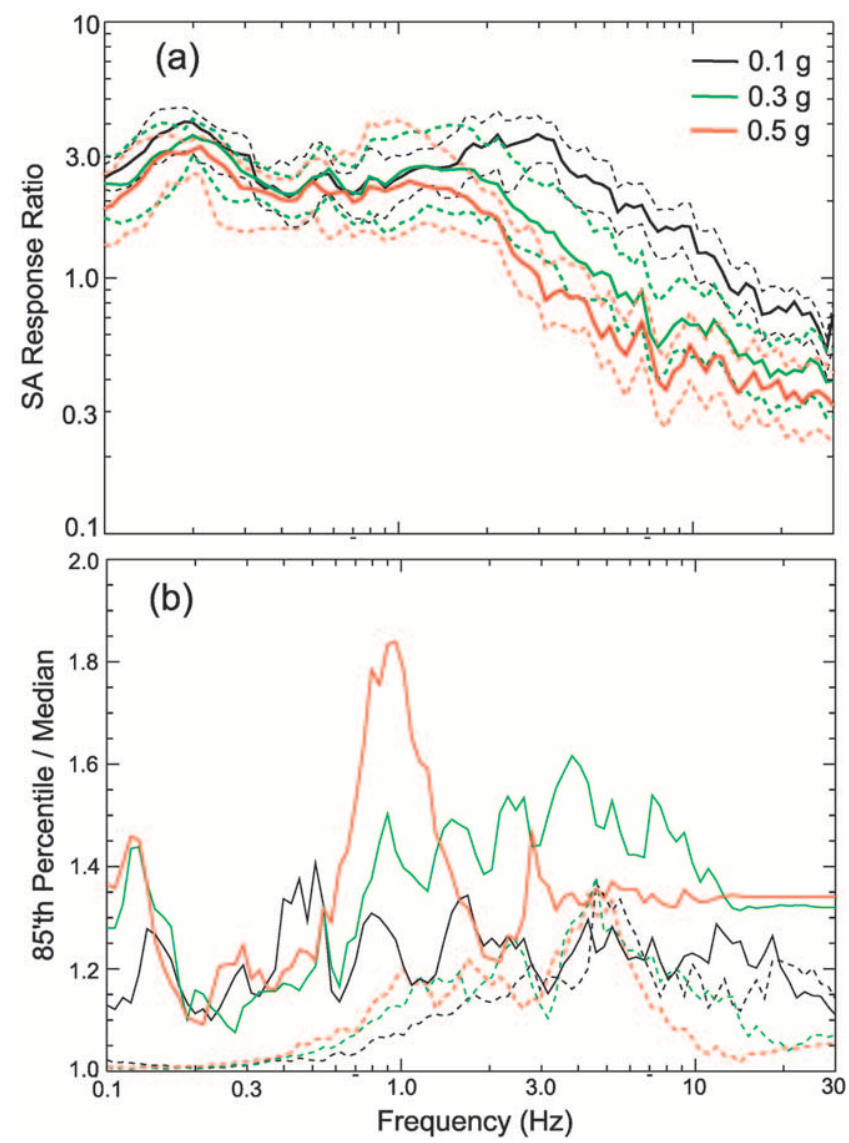

Figure 24. (a) SA response spectra ratios (ground surface/basement outcrop) based on randomized velocity model for Tertiary and Cretaceous units at a site in Charleston. Median response from 200 realizations is shown by the solid lines. Dashed lines indicate 15 th and 85 th percentile values. Different colors correspond to different input peak acceleration values. (b) Solid lines show the ratios of the 85th percentile to 50th percentile values in Figure 24a. The dashed lines show ratios of the 85 th to 50 th percentile response ratio values obtained from all 52 SCPT sites shown on the right side of Figure 21, which are based on the median velocity model for the Tertiary and Cretaceous section.

eling effort. The first feature is not sampled by the geotechnical data set. The contact between Coastal Plain sediments and the underlying Mesozoic volcanic and sedimentary rocks represents a major velocity contrast. Shear-wave velocity measurements are not available, but refraction, reflection, and drilling data collected approximately $25 \mathrm{~km}$ to the northwest of Charleston (Gohn, 1983) indicate that this interface probably juxtaposes weakly consolidated Cretaceous clastic sediments with Jurassic basalt and redbeds beneath the entire study area. We model this using an impedance contrast of 5.46 at a depth of $830 \mathrm{~m}$. This produces prominent amplification (SA response amplification factors of 3 to 4 ) at frequencies of approximately $0.2,0.6$, and $1.0 \mathrm{~Hz}$. This effect is modeled as common to all sites in the study area. 
The effect certainly varies somewhat over the entire study area because of lateral changes in both the thickness and velocity of the sedimentary section. However, such variation cannot be assessed at present. We expect such variation to be negligible over an area the size of the Charleston peninsula (see Fig. 1).

The second geological feature that is expected to strongly influence site response in the study area is the boundary between the soft Quaternary marine sediments and the stiffer Tertiary units. This was the focus of our modeling effort. We find that average shear-wave velocities in the Quaternary section are fairly uniform, ranging from approximately 150 to $250 \mathrm{~m} / \mathrm{sec}$. The average velocity within the Quaternary section does not appear to correlate with mapped surface geology. However, the shear-wave velocity in the uppermost Ashley formation (youngest unit of the Tertiary Cooper Group) ranges from approximately 300 to $500 \mathrm{~m} /$ sec at the 52 sites where shear-wave velocity measurements were available. Although the Quaternary-Tertiary interface is an irregular surface, there is a weak correlation between mapped surface geology and depth to the top of the Ashley. The Tertiary units are shallow at inland sites and become deeper toward the coast. At the 52 sites where shear-wave velocities are directly measured, the depth ranges from 10 to $30 \mathrm{~m}$. The mapped geological units roughly parallel the coastline and decrease in age toward the coast. Therefore, depth to the Tertiary tends to decrease with the age of the mapped surface geological unit. Another factor is that the ground elevation tends to be higher on beach ridge deposits, so that depth to the Tertiary tends to be larger on those surface units comprised of clean sands.

The calculated site-response effect of the variable depth to the Quaternary-Tertiary velocity contrast is manifest in the 1 - to $10-\mathrm{Hz}$ frequency range. The modeling predicts that sites on thicker sections (greater than $15 \mathrm{~m}$ ) of Quaternary sediment will have the larger response in the frequency band 1 to $3 \mathrm{~Hz}$, whereas sites on thinner Quaternary sediments will have the larger response at frequencies greater than approximately $3 \mathrm{~Hz}$. The modeling also suggests that larger $V_{30}$ values do not imply smaller SA response amplitudes at frequencies greater than $3-4 \mathrm{~Hz}$ in the study area.

Important uncertainties for the prediction of site response near Charleston involve the variation of velocity in the deeper Tertiary and Cretaceous sediments, and mechanical behavior (principally damping) as a function of strain and confining pressure in those deep sediments. Data to address these issues are currently lacking. Using a simple (poorly constrained but probably conservative) random velocity distribution for the deep Coastal Plain section, we estimate that variation of site response in the $1-$ to $10-\mathrm{Hz}$ frequency band at a given site due to uncertainty and potential spatial variation of velocity in the deeper sedimentary section is comparable with the variability of response due to the sampled lateral changes in geology in the upper $30 \mathrm{~m}$.
Note: A geographic information system coverage (ESRI ArcGIS Desktop version 8.2) containing some of the results of this study is available by contacting the principle author.

\section{Acknowledgments}

The study would not have been possible without the generous assistance of the following persons: William Camp, with S\&ME, Inc.; William Wright and Thomas Casey, with Wright, Padgett and Christopher, Inc.; James Duffy and Graham Forsythe, with Soil Consultants, Inc.; John Perryman, with Mactec, Inc.; and Timothy Cleary, with Gregg Drilling and Testing, Inc. We thank associate editor Francisco Chavez-Garcia and two anonymous referees for their constructive reviews that improved the article. The research was supported by the U.S. Geological Survey (USGS), Department of the Interior, under USGS Award Number 00HQGR0036. The conclusions are those of the authors and should not be interpreted as necessarily representing the official policies, either expressed or implied, of the U.S. Government.

\section{References}

Abercrombie, R. A. (1997). Near-surface attenuation and site effects from comparison of surface and deep borehold recordings, Bull. Seism. Soc. Am. 87, 731-744.

Ackerman, H. D. (1983). Seismic-refraction study in the area of the Charleston, South Carolina, 1886 earthquake, U.S. Geol. Surv. Profess. Pap. 1313-F, 19 p.

Assimaki, D., E. Kausel, and A. Whittle (2000). Model for dynamic shear modulus and damping for granular soils, J. Geotech. Geoenviron. Eng. 126, 859-869.

Assimaki, D., E. Kausel, and A. Whittle (2001). Errata, J. Geotech. Geoenviron. Eng. 127, 104.

Atkinson, G. A., and D. M. Boore (1995). Ground motion relations for Eastern North America, Bull. Seism. Soc. Am. 85, 17-30.

Bodin, P., and S. Horton (1999). Broadband microtremor observation of basin resonance in the Mississippi embayment, Central US, Geophys. Res. Lett. 26, no. 7, 903-906.

Bollinger, G. A. (1977). Reinterpretation of the intensity data for the 1886 Charleston, South Carolina earthquake, in Studies Related to the Charleston, South Carolina Earthquake of 1886: A Preliminary Report, D. W. Rankin (Editor), U.S. Geol. Surv. Profess. Pap. 1028, 17-32.

Boore, D. M. (2004). Can site response be predicted? J. Earthquake Eng. 8, Special Issue 1, 1-41.

Boore, D. M. (1983). Stochastic simulation of high-frequency ground motions based on seismological models of the radiated spectra, Bull. Seism. Soc. Am. 73, 1865-1894.

Boore, D. M., and G. M. Atkinson (1987). Stochastic prediction of ground motions and spectral response parameters at hard-rock sites in eastern North America, Bull. Seism. Soc. Am. 77, 440-467.

Boore, D. M., J. F. Gibbs, W. B. Joyner, J. C. Tinsley, and D. J. Ponti (2003). Estimated ground motion from the 1994 Northridge California, earthquake, at the site of the Interstate 10 and Las Cienega Boulevard Bridge collapse, West Los Angeles, California, Bull. Seism. Soc. Am. 93, 2737-2751.

Campanella, R. G. Research Students (1995). Guidelines for Geotechnical Design Using the Cone Penetrometer Test and CPT with Pore Pressure Measurement, Fifth Ed., Civil Engineering Department, University of British Columbia, Vancouver, British Columbia, Canada, $162 \mathrm{p}$.

Chapman, M. C., P. Talwani, and R. C. Cannon (2003). Ground motion attenuation in the Atlantic Coastal Plain near Charleston, South Carolina, Bull. Seism. Soc. Am. 93, 998-1011. 
Dutton, C. E. (1889). The Charleston earthquake of August 31, 1886, in Ninth Annual Report of the U.S. Geol. Surv., 203-528.

Frankel, A., C. Mueller, T. Barnhard, D. Perkins, E. V. Leyendecker, N. Dickman, S. Hanson, and M. G. Hopper (1996). National seismichazard maps: documentation June 1996, U.S. Geol. Surv. Open-File Rept. 96-532, 71 p.

Frankel, A. D., M. D. Petersen, C. S. Mueller, K. M. Haller, R. L. Wheeler, E. V. Leyendecker, R. L. Wesson, S. C. Harmsen, C. H. Cramer, D. M. Perkins, and K. S. Rukstales (2002). Documentation for the 2002 Update of the National Seismic Hazard Maps, U.S. Geol. Surv. Open-File Rept. 02-420, $31 \mathrm{p}$.

Gohn, G. S. (1983). Studies related to the Charleston, South Carolina, earthquake of 1886-tectonic and seismicity, U.S. Geol. Surv. Profess. Pap. 1313.

Hashash, Y. M. A., and D. Park (2001). Non-linear one-dimensional seismic ground motion propagation in the Mississippi embayment, Eng. Geol. 62, 185-206.

Hartzell, S., L. F. Bonilla, and R. A. Williams (2004). Prediction of nonlinear soil effects, Bull. Seism. Soc. Am. 94, no. 5, 1609-1629.

Ishibashi, I., and X. Zhang (1993). Unified dynamic shear moduli and damping ratios of sand and clay, Soils Foundations 33, no. 1, 182191.

Johnston, A. C. (1996). Seismic moment assessment of earthquakes in stable continental regions, III, New Madrid 1811-1812, Charleston, 1886 and Lisbon, 1755, Geophys. J. Int. 126, 314-344.

Laird, J. P., and K. H. Stokoe (1993). Dynamic properties of remolded and undisturbed soil samples tested at high confining pressure, Geotechnical Engineering Report GR93-6, Electrical Power Research Institute, Palo Alto, California.

Langston, C. A. (2004a). Local earthquake wave propagation through Mississippi Embayment sediments, Part I: Bodywave phases and local site response, Bull. Seism. Soc. Am. 93, 2664-2684.

Langston, C. A. (2004b). Local earthquake wave propagation through Mississippi Embayment sediments, Part II: Influence of local site velocity structure on Qp-Qs determinations, Bull. Seism. Soc. Am. 93, 26852702.

Liu, A., M. E. Wuenscher, and R. B. Herrmann (1994). Attenuation of body waves in the central New Madrid Seismic Zone, Bull. Seism. Soc. Am. 84, 1112-1122.

Lunne, T, P. K. Robertson, and J. J. M. Powell (1997). Cone Penetration Testing in Geotechnical Practice, Blackie Academic and Professional, London, United Kingdom, 312 p.

Mayne, P. W., and G. J. Rix (1993). Gmax-qc relationship for clays, Geotech. Test. J. 16, 54-60.

McCartan, L., E. M. Lemon, and R. E. Weems (1984). Geologic map of the area between Charleston and Orangeburg, South Carolina, U.S. Geol. Surv. Misc. Invest. Ser. Map I-1472.

Rix, G. J., and K. H. Stokoe (1991). Correlation of initial tangent modulus and cone penetration resistance, in Calibration Chamber Testing, International Symposium on Calibration Chamber Testing, A. B. Huang (Editor), Elsevier Publishing, New York, 351-362.
Schnabel, P. B., J. Lysmer, and H. B. Seed (1972). SHAKE: a computer program for earthquake response analysis of horizontally layered sites, Report UCB/EERC-72/12, Earthquake Engineering Research Center, University of California, Berkeley, $102 \mathrm{p}$.

Silva, W., I. Wong, T. Siegel, N. Gregor, R. Darragh, and R. Lee (2003). Ground motion and liquefaction simulation of the 1886 Charleston, South Carolina earthquake, Bull. Seism. Soc. Am. 93, 2717-2736.

Stover, C. W., and J. L. Coffman (1993). Seismicity of the United States, 1568-1989 (Revised), U.S. Geol. Surv. Profess. Pap. 1527, 418 p.

Talwani, P., and W. T. Schaeffer (2001). Recurrence rates of large earthquakes in the South Carolina Coastal Plain based on paleoliquefaction data, J. Geophys. Res. 106, no. B4, 6621-6642.

Weems, R. E., and E. M. Lemon (1984). Geologic map of the Stallsville Quadrangle, Dorchester, and Charleston Counties, South Carolina, U.S. Geol. Surv. Geologic Quadrangle Map GQ-1581.

Weems, R. E., and E. M. Lemon (1988). Geologic map of the Ladson Quadrangle, Berkeley, Charleston and Dorchester Counties, South Carolina, U.S. Geol. Surv. Geologic Quadrangle Map GQ-1630.

Weems, R. E., and E. M. Lemon (1993). Geology of the Cainhoy, Charleston, Fort Moultrie, and North Charleston Quadrangles, Charleston and Berkeley Counties, South Carolina, U.S. Geol. Surv. Misc. Invest. Ser. Map I-1935.

Weems, R. E., E. M. Lemon, and P. G. Chirico (1997). Digital geology and topography of the Charleston Quadrangle, Charleston and Berkeley Counties, South Carolina, U.S. Geol. Surv. Open-File Rept. $97-$ 531.

Williams, R. A., J. K. Odum, W. J. Stephenson, and D. M. Worley (2000). Determination of surficial S-wave seismic velocities of primary geological formations on the Piedmont and Atlantic Coastal Plain of South Carolina, Appendix C, in Site Response in the Atlantic and Gulf of Mexico Coastal Plains and Mississippi Embayment, C. Mueller (Editor), U.S Nuclear Regulatory Commission/U.S. Geological Survey Interagency Agreement RES-99-002, Report to NRC, 10 April 2000, A1-A5.

Yantis, B. R., J. K. Costain, and H. D. Ackerman (1983). A reflection seismic study near Charleston, South Carolina, U.S. Geol. Surv. Profess. Pap. 1313-G, 20 pp.

Department of Geosciences

4044 Derring Hall

Virginia Polytechnic Institute and State University

Blacksburg, Virginia, 24061

(M.C.C., J.N.B.)

Department of Civil and Environmental Engineering 200 Patton Hall

Virginia Polytechnic Institute and State University

Blacksburg, Virginia, 24061

(J.R.M., C.G.O.)

Manuscript received 30 March 2004. 